NBER WORKING PAPER SERIES

DO ENLARGED FISCAL DEFICITS CAUSE INFLATION: THE HISTORICAL RECORD

\author{
Michael D. Bordo \\ Mickey D. Levy \\ Working Paper 28195 \\ http://www.nber.org/papers/w28195 \\ NATIONAL BUREAU OF ECONOMIC RESEARCH \\ 1050 Massachusetts Avenue \\ Cambridge, MA 02138 \\ December 2020
}

Paper prepared for the IIMR Annual Monetary Conference "The Return of Inflation? Lessons from History and Analysis of Covid -19 Crisis Policy Response" organized by University of Buckingham, England, October 28 2020. For helpful comments on an earlier draft we thank: Michael Boskin, Andy Filardo, Harold James, Owen Humpage, Eric Leeper and Hugh Rockoff. For valuable research assistance we thank Roiana Reid and Humberto Martinez Beltran. The views expressed herein are those of the authors and do not necessarily reflect the views of the National Bureau of Economic Research.

NBER working papers are circulated for discussion and comment purposes. They have not been peer-reviewed or been subject to the review by the NBER Board of Directors that accompanies official NBER publications.

(C) 2020 by Michael D. Bordo and Mickey D. Levy. All rights reserved. Short sections of text, not to exceed two paragraphs, may be quoted without explicit permission provided that full credit, including $\odot$ notice, is given to the source. 
Do Enlarged Fiscal Deficits Cause Inflation: The Historical Record

Michael D. Bordo and Mickey D. Levy

NBER Working Paper No. 28195

December 2020

JEL No. E3,E62,N4

\begin{abstract}
$\underline{\text { ABSTRACT }}$
In this paper we survey the historical record for over two centuries on the connection between expansionary fiscal policy and inflation. As a backdrop, we briefly lay out several theoretical approaches to the effects of fiscal deficits on inflation: the earlier Keynesian and monetarist approaches; and modern approaches incorporating expectations and forward looking behavior: unpleasant monetarist arithmetic and the fiscal theory of the price level.

We find that the relationship between fiscal deficits and inflation generally holds in wartime when fiscally stressed governments resorted to the inflation tax. There were two peacetime episodes in the early twentieth century when bond financed fiscal deficits that were unbacked by future taxes seem to have greatly contributed to inflation: France in the 1920s and the recovery from the Great Recession in the 1930s in the U.S. In the post-World War II era a detailed examination of the Great Inflation in the 1960s and 1970s in the U.S. and the U.K. suggests that fiscal influences on monetary policy was a key factor. Finally we contrast the experience of the Great Financial Crisis of 2007-2008, when both expansionary fiscal and monetary policy did not lead to rising inflation, with the recent pandemic, which may involve the risks of fiscal dominance and future inflation.
\end{abstract}

Michael D. Bordo

Department of Economics

Rutgers University

New Jersey Hall

75 Hamilton Street

New Brunswick, NJ 08901

and NBER

bordo@econ.rutgers.edu

Mickey D. Levy

Berenberg Capital Markets LLC

1251 Avenue of the Americas, 53rd Floor

New York, NY 10020

mickey.levy@berenberg-us.com 


\section{Do Enlarged Deficits Cause Inflation? The Historical Record}

\section{Introduction}

The current global Covid -19 pandemic has led to massive government responses across the world, including lockdowns of normal activities and expansive fiscal and monetary policies to stabilize their economies and head off financial stresses. In the U.S. and UK and other advanced nations, expansive fiscal programs raised budget deficits and pushed debt-to-GDP ratios to the highest levels since World War II or in the preceding two centuries. See figures 1 and 2. Central banks lowered interest rates to zero, introduced extensive lender of last resort and credit facilities and engaged in large-scale asset purchases of government bonds. The low interest rates and central bank purchases of government bonds lowered debt service costs and facilitated the dramatic fiscal expansions.

In many respects, the initial response combined aspects of the policy response in several overlapping crisis scenarios in the past: World Wars I and II, the Great Depression, and the Global Financial Crisis (Bordo, Levin and Levy 2020). These earlier episodes of induced fiscal and monetary expansion in the 1930s and the World Wars led to rising price levels and inflation. In this paper we survey the historical record for over two centuries on the connection between expansionary fiscal policy and inflation and find that fiscal deficits that are financed by monetary expansion tend to be inflationary. However, some research finds that money finance is not required for an inflationary outcome. ${ }^{2}$

In section 2 we briefly lay out several theoretical approaches to the effects of fiscal deficits on inflation: the earlier Keynesian and Quantity theoretic approaches; and modern approaches incorporating expectations and forward looking behavior:unpleasant monetarist arithmetic and fiscal theory of the price level. In section 3 we survey the historical wartime records, distinguishing between earlier wars of the eighteenth century including the Napoleonic wars, and modern wars including the World Wars, Korea and Vietnam. In section 4 we examine the peacetime episodes in the interwar period of the twentieth century linking fiscal expansion to

\footnotetext{
${ }^{2}$ Earlier surveys by Schwartz (1973) and Capie (1979) cover some of the same ground.
} 
inflation. In section 5 we focus on the Great Inflation of the 1960s-1970s in the U.S. and the U.K. Section 6 covers the recent experience since the 2008-2009 Great Financial Crisis in which high deficits did not result in inflation and the experience of the pandemic, which may involve future inflation risks. We conclude in section 7 with some policy lessons, particularly in light of historically high deficits.

\section{Theoretical Perspectives}

In the post-World War II era two theories have dominated economists approaches to the link between fiscal deficits and inflation.

Simple Keynesian models. The prevalent view on the relationship between fiscal deficits and inflation is based on the post-WWII Keynesian models that posited that any increase in aggregate demand (consumption expenditures, investment expenditures, government expenditures less tax receipts and exports less imports) will lead to an increase in nominal income. The extent to which it leads to a rise in the price level depends on the shape of the aggregate supply curve. The early Keynesians also argued that monetary policy would be impotent because the economy was in a liquidity trap so that money does not matter. Accordingly, fiscal policy is the only tool to influence the economy ${ }^{3}$. The early Keynesians posited an L-shaped supply curve in which shifts in aggregate demand would result in increase in real activity until full employment is reached, when expansionary demand would be reflected in rises in the price level. In the early Phillips curve framework, the supply curve is positively shaped so that expansionary aggregate demand would lead to both rising prices and output (Lipsey 1960). Thus, fiscal policy can be inflationary in Keynesian models.

Simple quantity theory of money. Changes in nominal income are generated by changes in the money supply assuming a stable money demand function that determines the income velocity of money. Inflation (sustained increases in the price level) requires sustained money growth (Friedman 1956). Once increases in inflation become expected, higher nominal interest rates reduce the demand for money such that faster money velocity amplifies the effect of money

\footnotetext{
${ }^{3}$ The early Keynesian models did not explicitly discuss how fiscal deficits would be financed other than by taxes.
} 
supply on prices. Early monetarists also posited that fiscal policy, unless it was money financed, as during wars when central banks were subservient to the fiscal authorities, would have no influence on nominal income or price movements (Anderson and Jordan 1965).

Modern approaches. Forward looking behavior and inflationary expectations play a central role in recent approaches built upon the earlier Keynesian and monetarist approaches. The heightened importance of inflationary expectations was initiated and reinforced by the Great Inflation of 1965-1980. Expectations of inflation are reflected in financial markets and affect real economic activity, and are integral to the inflation process. Adjustments of inflation expectations operate as constraints on the efficacy of countercyclical fiscal policies and excessively easy monetary policy.

Fiscal dominance of monetary policy. Fiscal dominance posits that persistent deficits and mounting debt exert pressures on the central bank to follow inflationary monetary policy. Sargent and Wallace (1980) "Some Unpleasant Monetarist Arithmetic" extended the monetarist approach in a dynamic setting with rational expectations and perfect foresight. In that environment fiscal deficits, even if they are financed by the issuance of government bonds, ultimately will be accommodated by inflationary increases in high powered money to satisfy the governments' long-run consolidated balance sheet.

The Fiscal Theory of the Price Level (FTPL). Sims (2011), Leeper (1991), Cochrane (2019) argue that if fiscal deficits are persistent and taxes are not raised or expenditures cut in the future sufficiently to prevent an explosion of national debt, this will lead to a state of fiscal dominance. Economic agents will perceive the increase in nominal government debt to be an increase in real wealth. The wealth effect will lead to increased consumption expenditure and to rising prices that will reduce the real value of the national debt and restore fiscal equilibrium. According to Jacobson Leeper and Preston (2019) when fiscal policy is active (dominant), increased government spending induces both the traditional Keynesian multiplier and a more powerful debt multiplier.

In both modern approaches, fiscal deficits are expansionary. In the Sargent and Wallace framework, fiscal deficits are inflationary because they lead to monetary expansion in the 
quantity theory tradition. In the FTPL, fiscal deficits are inflationary by themselves in the tradition of the Keynesian approach.

\section{Evidence from History: Wars}

In this section, we review some salient episodes in modern economic history of fiscal deficits associated with inflation in wartime in the eighteenth, nineteenth and twentieth centuries. ${ }^{4}$ Three salient episodes stand out in the eighteenth century: the Swedish experience with fiat money in the Seven Years war, the Continentals in the American Revolution and the Assignats in the French Revolution.

\subsection{Sweden: The Seven Years War}

The Riksbank, the earliest central bank, was founded in 1668. It was chartered by and owned by the Swedish parliament, the Riksdag (Fregert 2018). Its mandate was to be a depository for the government's revenues, to provide a safe means of payment and to maintain convertibility of its notes into specie. It was originally supposed to be independent of the government. After 1720, the Riksbank shifted from being independent of the government to being controlled by it and becoming a tool for fiscal policy.

In 1745 , the expansionist, soft money Hat Party, which was mercantilist and hawkish, took control of the government from the more conservative Cap Party that favored hard money) (Eagly 1969). The Riksbank began expanding its notes to finance the war against Russia leading to a suspension of convertibility. Money financed fiscal deficits burgeoned later in the Seven Years War with a tripling of the note issue (Fregert and Jonung 1996). This led to significant inflation and depreciation of the currency by a half of its 1745 value. A return to power of the Caps in 1765 set in play deflationary policies to restore price stability and resume convertibility in 1777 . This episode is considered the earliest use of fiat money fiscal finance.

\subsection{The American Revolutionary War 1775-1781}

\footnotetext{
${ }^{4}$ There is a considerable body of research on debasement and seigniorage in the middle ages and the early modern period not covered here.
} 
The War of the American Revolution was an early prominent example of the use of inflationary finance to pay for the war. In wartime, governments need to finance unusual expenditure by reallocating resources from peacetime to wartime uses. This requires the use of taxation, borrowing or the issue of fiat money, sometimes called seigniorage, which is the tax on real cash balances. Relying on taxes as a source of financing wars in the eighteenth century was difficult and limited because tax revenues were inelastic. Taxes were derived mainly from indirect taxes, which were often evaded, while direct taxes were not popular and the governments were not organized to administer them. Moreover, sufficiently large increases in taxation to finance the war efforts could reduce labor effort during a time when it is needed most.

In its many wars of the eighteenth century, the British government, in addition to raising taxes, began using a policy of tax smoothing, which involved financing wars by the issue of government debt that would be repaid after the war by continuing war time taxation rates (Barro 1979,1987). This tax smoothing scheme for financing war may have been an important reason for Great Britain's martial success. A key determinant of Great Britain's ability to issue so much debt was the efficiency and credibility of its fiscal system (Dickson 1967, Brewer 1989). In the more costly wars of the subsequent two centuries, debt finance was also supplemented by the issue of paper money, following the suspension of the specie standard. ${ }^{5}$

The American revolutionary government was unable to adopt the British model. The Congress did not have the power to levy taxes directly and could not raise adequate tax revenue. The states had the power to tax, but they were unwilling to raise adequate tax revenue in part because the revolution was fought over the issue of taxation. Moreover, the Congress and the states found it very difficult to borrow because those colonists who had wealth were unwilling to lend because of the risk that the British would repudiate the debt were they to win. Foreign loans were not forthcoming for the same reason until 1780, when France and Spain joined the war on the Americans side. Thus, the revolutionary government had to resort to the issue of

\footnotetext{
${ }^{5}$ The theory of optimal taxation (Mankiw 1987) posited that an optimal taxation strategy using a combination of taxes, debt and seigniorage would minimize the marginal excess burden of the three instruments. This makes the case for some inflationary finance in major wars.
} 
paper money-bills of credit. Citizens accepted this practice because it had been widely used by many of the colonies in the preceding century.

The evidence suggests that over three quarters of government expenditure was financed by fiat money. The Congress issued bills of credit called continentals. Initially the Congress pledged that the bills would be retired by state taxes on the assumption that the war would be brief. This assumption did not hold up, and the bills were issued without the pretext of convertibility. The states also issued bills and notes.

The issue of paper money to finance the war has been viewed as a tax on real cash balances (Friedman 1969). Just like any tax, a government with monopoly power can calculate the revenue-maximizing rate of taxation. Modern studies have estimated the revenue-maximizing rate of inflation in emerging countries in the late twentieth century that had a history of high inflation in the twentieth century as between 100-350\% per year (Easterly, Mauro and SchmidtHebbel 1995. Rockoff (2016) calculates that the average rate of inflation during the Revolutionary war was about $22 \%$ per year, which suggests that the American revolutionary government was very conservative in its use of inflationary finance.

\subsection{The Assignats in the French Revolution}

In the eighteenth century, France was unable to follow the British example of tax smoothing (Bordo and White 1991). As White $(1989,1995)$ demonstrates, France's tax collection was both inefficient and corrupt. In 1759, in the midst of the Seven Years War, the Crown was forced to suspend repayment of the principal on a variety of short-term debts. Later, the continuing fiscal crisis after the war eventually led to a partial bankruptcy in 1770 . The government attempted to restore fiscal balance until the American War of Independence led to large deficits. Subsequent reforms were unsuccessful (White 1995). By 1787, the Parliament realized that the Crown would not be able to balance its budget. According to White (1995) the fiscal crisis precipitated the French Revolution when the Parliament refused to sanction new taxes or loans.

After the end of the monarchy, the National Assembly chose to seize the lands of the Church and sell them through auction and use the proceeds to cover the deficit and redeem the 
unfunded debt. This led to the creation of the assignats, notes backed by the value of the Church properties. As the Revolution continued, attempts to redeem the assignats ceased and they were increasingly used to cover the fiscal deficits. Once war broke out in 1792, the government fully covered the deficits with assignats. The issue of assignats led to increasing inflation and by 1795 a hyperinflation. The assignats were similar to other schemes in the eighteenth century to issue note based on the nominal value of land. Rhode Island had a similar experience. It increased note issuance, which led to inflation that increased the nominal value of the land. This led to further money issue, eventually leading to hyperinflation.

\section{Modern Wars}

Below we discuss the financing of four major wars in the nineteenth and twentieth centuries in the UK and the US. In all cases, the majority of wartime expenditures was financed by borrowing and running fiscal deficits. The fiscal deficits were also accommodated to a differing degree by expansionary monetary policy, leading to inflation and the inflation tax. There were numerous minor wars that were also funded by taxation that did not involve debt issue or seigniorage. A major modern exception was the Korean war which the U.S., which was primarily financed by raising taxes (See Ohanian 1997).

\subsection{The Napoleonic Wars: Great Britain}

The war against France was initially financed in the traditional eighteenth-century style of tax smoothing. According to O' Brien (1967), 90\% of wartime expenditure between 1793 and 1798 were covered by borrowing. The massive scale of expenditures required far greater expenditures, so large deficits persisted for a longer than previous wars, which increased pressures on government finance (see figure 3).

Britain fought the wars of the eighteenth century on the specie standard but the circumstances of the late 1790s forced a suspension of payments in February 1797. Pressure on the Bank of England's (BoE's) gold reserves began with a financial crisis at the outbreak of war in 1793. As the war continued the BoE had increasing difficulty in financing the government's war demand (short-term bills) amid demands from commerce and maintaining convertibility. To prevent the 
perceived collapse of the BoE in the face of both a massive external drain and a run on the country banks occasioned by fears of a French invasion, the government finally allowed the bank to suspend specie payments on February 26, 1797.

After the Bank suspended specie payments, the government was again able to sell much of its short-term debt to the BoE. Historians generally viewed accommodation of both government and private borrowing as the way in which the bank contributed to war finance (Fetter1965, Schumpter1938, Silberling 1923 and Viner 1937). Both the BoE's note issue (figure 4) and the price level (figure 5) rose considerably during the period.

At the time, there was heated debate between the Bullionists and anti-Bullionists over whether the inflation was caused by monetary or real forces, but the availability of better data supports the former view (Bordo and Schwartz 1980,1981). The fact that private borrowers could discount commercial and government paper freely at the five per cent usury ceiling when the nominal interest rate was surely higher, reflecting inflation rate up to $10 \%$ annually, suggests that the indirect mechanism originally pointed out by Thornton (1802) was important. ${ }^{6}$ The British experience in the first modern world war with inflationary finance set the stage for war finance in later wars in the nineteenth and twentieth centuries. However, its contribution was modest accounting for less than 10\% of the fiscal deficit (Bordo and White 1991 Table 3).

\subsection{The US Civil War 1861-1865}

Unlike the American Revolutionary War, the Federal (Union) Government had access to capital markets and financed most of its Civil War expenditures by borrowing (62\%), then taxes (21\%) and lastly seigniorage (13\%) (Friedman and Schwartz 1963). The ratio of debt-to-GDP increased from negligible to 35\%, far less than during the Revolutionary War (Hall and Sargent 2020). Within a year after hostilities began, the Federal Government found it increasingly difficult to obtain favorable terms for its bonds and following the suspension of specie payments in December 1861 began in February 1862 the issue of fiat money, greenbacks that were non-

\footnotetext{
${ }^{6}$ More recently Antipa and Chamley (2017) have challenged the Bullionist/monetarist explanation arguing that according to the fiscal theory of the price level it was announcements of unbacked (by future taxes) fiscal policy not the Bank of England's note issue that drove movements in the price level.
} 
interest-bearing notes denominated in dollars and declared to be legal tender. These notes were issued on the presumption that they would be convertible into specie but the date and provisions for convertibility were not clearly stated. The total amount of greenbacks created was $\$ 450$ million. The greenbacks were supplemented by national bank notes issued by the newly created (1863) national banking system. The average inflation rate in the Union was $25 \%$ per year. Once hostilities ceased, efforts began to reverse the debt build up through running primary budget surpluses to retire the greenbacks. However, it took until 1879 to restore price stability and reduce most of the accumulated debt. ${ }^{7}$

\subsection{World War I 1914-1918}

The unprecedented scale and duration of World War I led all of the belligerents to engage in massive fiscal expansion. The UK's debt-to-GDP ratio peaked at $140 \%$, France close to $200 \%$ and the US, which joined the war 3 years later, 35\%, similar to the Civil War. The U.S.'s bond finance accounted for the lion's share of the financing, followed by taxes and then seigniorage, with a 5\% share (Friedman and Schwartz 1963). For all nations, the central bank acted as an engine of inflation by following low interest pegs to aid the fiscal authorities. The Federal Reserve discounted member bank bills, secured by government obligations at a fixed discount rate below the market rate of interest. This policy generated a 10\% per year growth in the M2 money supply and $12 \%$ inflation. In the UK, inflation ran at $25 \%$ per year. After the war the US, UK and many other countries aimed to restore the gold standard by monetary contraction and fiscal retrenchment according to the tax smoothing framework (Ahamed 1986, Bordo and Bayoumi 2000). This led to a serious recession in 1920-21. Countries success in returning to a gold standard depended on the extent of their monetary and fiscal expansion during the war and the underlying political economy (Eichengreen 1992, Bordo and Hautcoeur 2007)

\subsection{World War II 1939-1945}

\footnotetext{
${ }^{7}$ In the Confederacy (the Southern states), with much more limited access to the capital markets and a smaller tax base, $60 \%$ of the war was financed by the issue of paper money. This led to a hyperinflation. Confederate money and debt were declared worthless after the union victory in April 1865 (Lerner 1956).
} 
World War II was financed in a similar manner. In the U.S, government spending increased to $32 \%$ of GDP, financed by taxes (42\%), bond issuance (34\%) and the inflation tax (24\%) (Friedman and Schwartz, 1963). The ratio of gross debt to GDP rose to $120 \%$. The patterns were similar in the UK.

During the war, the U.S.'s fiscal spending was accommodated by the Federal Reserve, which gave up its independence to the Treasury, implementing a low interest rate peg $3 / 8 \%$ on shortterm Treasuries and $21 / 2 \%$ on long-term Treasuries) to minimize the costs of debt issuance (Humpage 2016). The inflationary consequences of this policy were somewhat mitigated by wage and price controls. Reflecting these controls, WPI inflation was 9\% per year 1939-1945 and $4.5 \%$ per year during $1941-1945$.

At the end of the war, policy makers feared a repeat of the deflation and recession that followed World War I, reflecting tight monetary policies to maintain adherence to the gold standard. It was widely agreed that it was the government's role to manage aggregate demand (Stein 1994). They ignored the pent -up consumer spending demand and surge in business investment that began once hostilities ceased and rationing ended. Consequently, the accommodative low interest peg policy was continued, which fueled rapid inflation once price controls were removed (WPI inflation averaged $11.5 \%$ per annum 1945-1948). In comparison to the preceding big wars, the post-World War II era was not characterized by the deflation that led to a return to gold convertibility, nor did the advanced countries shift to tight fiscal policies as under the tax smoothing framework. The big debt build ups were gradually reduced by a combination of inflation, rapid growth and financial repression (Grossman 1990, Aizenman and Marion 2010, Reinhart and Srbancia 2015)

\section{Peacetime Episodes of Fiscal Expansion and High inflation}

In this section we consider several examples where expansionary fiscal policy was associated with inflation in peace time: the high inflation in France in the 1920s; the recovery from the Great Contraction in the US in the 1930s; the Great Inflation in the US 1965-1979 and the Great Inflation in the UK 1965 to 1980. 


\subsection{France in the $1920 \mathrm{~s}$}

Most of the defeated powers after World War I faced hyperinflations that collapsed their economies, tax bases and fiscal systems and generated extreme political dysfunction (Eichengreen1992). France stood out as a major victor from the war, but experienced high inflation associated with fiscal instability. France's fiscal experience in the 1920s is a good example of fiscal dominance that has resonance for the recent Fiscal Theory of the Price Level (Leeper and Walker 2011).

A contrast between Great Britain, which followed a policy of active monetary policy and passive fiscal policy, helps make the case (Bordo and Hautcoeur 2007). Both countries emerged from World War I with more than a doubled price level (figure 6), a high ratio of debt-to-GDP (figure 7), large fiscal deficits (figure 8) and a devalued exchange rate (figure 9). France was in worse shape than Britain in all dimensions but not by much. The key difference between the two countries was their fiscal and monetary stances after the war. France had a higher debt ratio, more short-term debt and a big monetary overhang. France had extensive destruction of its physical capital stock but also a faster growth rate than Britain. The UK was able to manage a successful stabilization and resumption to the gold standard at the original parity beginning in 1919 and culminating in April 1925. France delayed policy stabilization, going back to gold in December 1926 with an 80\% depreciation in the franc. More importantly, France had 6 years of rapidly rising prices. This was consistent with the FTPL model of Leeper and Walker (2011), Cochrane (2019), as the rise in the price level reduced the real value of the national debt. Fiscal balance was retired in 1926 by a political compromise between the left and the right that involved rising taxes and reducing government expenditure. France's fiscal problems in the 1920s are well known (Eichengreen 1992). First, like Britain, France financed World War I with a combination of taxes, debt and seigniorage, but it raised taxes by less and relied more on debt financing (see figures 7 and 8). In both France and the UK, the central banks absorbed Treasury bills and pegged short-term interest rates.

Second, France did not have the same political commitment to stabilization as the British, for three reasons: a) reparations -the belief that German reparations would pay for reconstruction; 
b) a political struggle between the left and the right over who would cover the fiscal deficit once it became apparent that the Germans would not pay (the left wanted to impose a capital levy and the right wanted to raise excise and other taxes); and c) the French had monetized more of their short-term debt than did the British and consequently had a larger monetary overhang, requiring more deflation to get back to the pre-war parity. Moreover, the government had to repay its short-term debt to the Banque de France, which in turn would raise the deficit and the debt.

The political tug of war continued for seven years with several changes of government and many finance ministers. Instead of raising taxes and cutting expenditures sufficiently to balance the budget, the government kept issuing short-term bills that were difficult to sell and roll over, and consequently were absorbed by the (passive) Banque de France. This led to inflation and a depreciating exchange rate.

The political impasse was finally broken in July 1926 when a revolt by left-wing deputies in Parliament led to an invitation to Raymond Poincare (center right) to take over the government and to rule by decree. He raised taxes, cut expenditures and was able to borrow dollars from JP Morgan and Lazards and use the funds to conduct a bear squeeze on speculators selling the franc short. This stabilized the franc, which was then pegged to gold at a greatly depreciated rate. $^{8}$

\subsection{The Recovery from the Great Contraction in the US 1933-1936}

Friedman and Schwartz (1963) and Meltzer (2005) attribute the Great Contraction in the U.S. from 1929-1933 when output and prices each fell by a third to a collapse of the money supply brought upon by a policy failure of the Federal Reserve. The contraction ended in March 1933. Friedman and Schwartz attribute the subsequent recovery to the bank holiday that ended the fourth banking panic, as well as President Franklin Delano Roosevelt's decision to leave the gold

\footnotetext{
${ }^{8}$ Bordo and Hautcoeur (2007) simulate a model of the French economy in the 1920s and show that it was impossible for France to engineer a British style stabilization and resumption. This is because following the British route of consolidating debt and deflation would have increased French debt unsustainable levels. This suggests that France had to have a huge increase in the price level and a major devaluation to achieve fiscal equilibrium.
} 
standard and devaluing the US dollar by close to $40 \%$. They argued that recovery was fueled by an increase in the monetary gold stock, reflecting FDR's gold purchase policy following the advice of George Warren, and the profits from the currency devaluation that greatly expanded the monetary gold stock and gold inflows from Europe, which accompanied capital flight from a growing political uncertainty. This view was empirically supported by Romer (1992). Recently the Friedman and Schwartz position has been challenged by Eggertson (2008) who posited that it was a fiscal/monetary regime change brought about by FDR's abandoning the gold standard that led to a rise in inflationary expectations. ${ }^{9}$

Jacobson, Leeper and Preston (2019) argue that the reflation can be explained by unbacked fiscal expansion after the US left the gold standard. They argue based on the FTPL that adherence to the gold standard meant that any fiscal expansion had to be fully backed by future taxes. Once the gold standard constraint was removed, the Treasury could run unbacked fiscal deficits. Then according to the FTPL this would lead to a rise in nominal debt which in turn would lead to an increase in household expenditure and by a wealth effect would raise the price level. Consistent with Meltzer (2005), they emphasize that the Fed was not following active monetary policy. Hence, similar to the French case in the 1920s, inflation could be attributed to an active fiscal and passive money regime.

The evidence is based on a large increase in emergency expenditure measures (New Deal programs including the WPA, AAA and CCC) that were not ( perceived by the public to be) backed by future taxes. This allowed gross nominal debt to rise by $40 \%$ in 7 years. The increase in nominal debt raised wealth and nominal aggregate demand. This evidence combined with the results from vector auto regression analysis (VARS) lead them to conclude that fiscal expansion explained the 1930s reflation.

\section{The Great Inflation 1965 to 1982}

\footnotetext{
${ }^{9}$ Also see Jalil and Rua (2017), who also attribute the recovery to a change in inflationary expectations.
} 
We focus on two recent important episodes of peacetime inflation associated with fiscal expansion in the U.S. and the U.K.

\subsection{The Great inflation in the U.S. 1965-1979}

Following the Federal Reserve -Treasury Accord of February 1951 that released the Fed's policy making from the Treasury's fiscal needs, the Fed was led by Chairman William McChesney Martin, a fiscal conservative, consistent with the conservative fiscal policies of the Eisenhower Administration (Meltzer 2010, Stein 1994).

The underlying ideology of macroeconomic policy changed from classical orthodoxy to Keynesianism in the 1960s, as the Kennedy and Johnson administrations placed the highest priority on increasing US growth and reducing unemployment using aggregate demand management policies and relying on the Phillips Curve as their guideline.

Council of Economic Advisors Chairman Walter Heller and then Arthur Okun perceived that the welfare costs of inflation were lower than the costs of unemployment. The Keynesians also believed that fiscal policy was a more potent tool of demand management than monetary policy, and both monetary policy and fiscal policies should be used to fine-tune the business cycle (Stein 1994).

The confluence of activist fiscal policies and the persistence of deficits accommodated by monetary ease dominated the inflationary environment of 1965-1980. The story was similar in the UK. In addition, both in the US and UK, policymakers believed that inflation was caused by cost-push factors rather than easy money and favored incomes policies-wage and price controls to combat inflation.

The 1964 Kennedy tax cut increased the fiscal deficit (See figure 10), and the Fed began accommodating fiscal policy through its even keel operations (Meltzer 2010, Humpage 2015) ${ }^{10}$. Martin attached considerable importance to cooperating with the administration and his

10 "Even keel" refers to the Fed's policy of holding interest rates steady during Treasury funding operations. Beginning in the 1960s the Fed increasingly held rates below what its policy instincts suggested as the Treasury kept increasing its funding operations. Humpage and Meltzer's calculations suggest that even keel may have explained up to half of the Fed's monetary expansion. 
concept of central bank independence was "independent within the government". As a consequence, money growth began increasing along with fiscal deficits (see figure 11). Inflation had been modest through 1965 and then accelerated with the buildup in government expenditures for the Vietnam War and President Lyndon Baines Johnson's Great Society programs (figure 12) and monetary accommodation. In 1966-1967, the Fed's monetary tightening led to the Credit Crunch and mini-recession when rising rates surpassed the regulation Q ceiling rate on time deposits and led to a decline in mortgage finance. In response, Congress and particularly LBJ placed extreme pressure on the Fed to maintain monetary ease, and the Fed refrained from raising rates as deficit spending on the Vietnam War and domestic programs boosted aggregate demand. LBJ's verbal attack on Martin on a visit to his Texas ranch following the FOMC's decision to raise the discount rate by 50 basis points in late 1965 was identified by Meltzer and others as an experience that significantly weakened Martin's anti-inflation resolve (Meltzer 2010). Inflation increased and so did inflationary expectations and bond yields. The Fed did not begin serious tightening monetary policy until after LBJ announced that he would not seek re-election for President in March 1968. By then, inflation had risen to $4 \%$ from its $1.25 \%$ average during $1960-1965$.

Meltzer (2010 chapter 4) summarized Fed policy during this early stage of the Great Inflation as prioritizing unemployment over inflation, reflecting both ideology - the adoption of Keynesian doctrine--and political pressures to avoid rising unemployment. The tug and pull between the ideologies led to alternating periods of expansionary monetary policy (and fiscal policy) followed by tightening and then back again. The monetary expansion would generate lower unemployment and higher inflation with a lag, followed by Fed tightening aimed at reducing inflation. The subsequent rise in unemployment led to political pressure that would encourage the Fed to abandon its tightening. Meltzer believed these actions convinced the public that the Fed did not attach high priority to inflation, which became more and more persistent as inflationary expectations became embedded in the public conscience. ${ }^{11}$ The persistence of inflationary expectations and the failure of the Fed to address it became a critical theme of the 1970s.

\footnotetext{
${ }^{11}$ For further explanations of the Great Inflation see Bordo and Orphanides 2013.
} 
Richard Nixon campaigned for President on a fiscally conservative platform of rolling back the expansionary aggregate demand policies and the liberal agenda of the preceding Democratic administrations. Although Nixon was influenced by the views of Milton Friedman and posited a greater role for free markets, monetary gradualism to reduce inflation, and full employment balanced budgets, his real focus was foreign policy and not economics, and he did not follow his platform on either fiscal or monetary policy. Nixon appointed Arthur Burns, who had been a close advisor since 1960 and a student and friend of Milton Friedman, as Chairman of the Fed. Burns was viewed as an advocate of sound money but not monetary rules (Meltzer 2010, Wells 1994). In fact, his views on inflation were eclectic, and tilted toward incomes policies-wage and price controls - as a way to combat inflation.

When Burns became Fed Chair in February 1970, inflation was high and the economy was in recession generated by tight monetary policy and the 1968 "Vietnam War tax surcharge". Worried about budget deficits, the Nixon Administration did not rollback the Johnson surcharge, adding to the recession and rising unemployment in 1970. Although inflation remained above $6 \%$, Burns was reticent to tighten monetary policy and instead began formally advocating wage and price controls, arguing that the key determinant of inflation was cost-push pressure by big labor unions and large firms with considerable market power. ${ }^{12}$ Nixon pressured the Fed to lower interest rates aggressively (from $8 \%$ to $4.9 \%$ by year-end 1970). Inflation receded to $3.5 \%$ by year-end, but inflationary expectations did not fall commensurately. The U.S. was facing mounting international financial tensions stemming from an erosion of credibility of its monetary system and inflation that was contributing to pressures on U.S. gold reserves. In August 1971, with full support of Burns, Nixon cancelled the direct international convertibility of the US dollar into gold, effectively abandoning the Bretton Woods system, and imposed wage and price controls (Bordo 2018).

Burns purposely pursued easy monetary policy during Nixon's 1972 Presidential election campaign, upholding his promise to Nixon on the day that he was installed as Chairman "You

\footnotetext{
12 See Shultz (2018) who unearthed a letter from Burns to Nixon dated June 221971 when he explicitly advocated wage price controls.
} 
see to it: no recession" (Wells 1994 page 42). ${ }^{13}$ During 1972, as the economy recovered strongly from recession, the Fed was purposely slow to raise rates, so money supply accelerated sharply. This spurred aggregate demand in 1973 while the wage and price controls constrained measured inflation, generating strong real growth. The wage and price controls generated widespread economic distortions, undercutting productivity and the government's credibility. (Stein 1994).

The Arab oil embargo and surge in oil prices beginning in November 1973 generated a deep recession and higher inflation, and greatly exacerbated the distortions imposed by the wage and price controls. The Fed lowered rates, accommodating the negative oil price shock. When the price controls were actually lifted in April 1974, inflation soared over $11 \%$ by year-end. This depressed real incomes, exacerbating and extending the recession through early 1975 and lifting the unemployment rate above $10 \%$.

In response to concerns about high unemployment and poor economic performance, the Fed lowered rates aggressively from 12\% in Fall 1974 to 5.2\% at year-end 1975 and $4.7 \%$ in early 1977. The Fed's monetary base-bank reserves plus currency-and the broader monetary aggregates accelerated throughout the decade.

Despite the modest fiscal policy responses to the deep 1973-1975, persistent deficits emerged in the 1970s, a new peacetime characteristic of government finances. Longer-run projections of significant increases of spending on entitlement programs and persistent budget deficits received significant attention.

The second half of the 1970s involved high and rising inflation that stemmed from easy monetary policy by the Burns-led Fed, and various non-monetary strategies by the Carter Administration to corral inflation that were based on the belief that inflation derived from costpush pressures (Greenspan, Kahn, Kosters and Daly 1978). Inflationary expectations became

\footnotetext{
${ }^{13}$ Nixon also said about Burns, "I respect his independence. However, I hope that independently he will conclude that my views are the ones that should be followed' (Wells 1994 page 42)
} 
embedded in financial and economic behavior. This culminated in a loss of global confidence in the US dollar and a currency crisis in late 1978.

As inflation rose, the Fed and the Carter Administration did not want to tighten monetary policy because the costs of reducing inflation were perceived to be too high (Burns 1978). Congress pushed for lower unemployment and enacted the Full Employment Act of 1978 that amended the Employment Act of 1946, mandating the goals of $4 \%$ unemployment with inflation not over 4\%. It also instructed the government to take reasonable means to balance the budget and achieve a balance in trade. The Congressional debate was driven largely by the frameworks provided by activist Keynesianism and the Phillips Curve, without regard to the monetary sources of inflation. This legislation had little immediate impact on monetary or fiscal policies during the remainder of the 1970s.

In the four years $1976-1979$, nominal GDP rose at an average annual rate of $11.75 \%$. Real economic growth held up through 1978, as inflationary expectations were slow to rise to reflect the situation, but the higher inflation eroded the underlying fundamentals. It reduced real purchasing power and raised real taxes by pushing taxpayers into progressively higher tax brackets, reducing real disposable incomes. The higher inflation also increased the cost of capital and harmed businesses. (Feldstein 1983).

The rising inflation and the unwillingness of the Fed to tighten monetary policy and reduce inflation, along with the persistence of budget deficits, eroded confidence and the government's credibility. In February 1978, President Carter announced that he would not reappoint Burns as Fed Chairman and subsequently replaced him with G. William Miller, who maintained an accommodative monetary policy until Volcker became Chair in August 1979. The Carter Administration favored wage and price controls to control inflation, and in October 1978 , imposed a wage-price guidelines program that assigned voluntary limits of $7 \%$ increase on wages and $5.75 \%$ increases on prices and an array of government sanctions. These sanctions were monitored by the Council on Wage and Price Stability, which had been established by the Nixon Administration to manage the failed wage and price controls of 1971.

Carter's wage-price guideline programs only reinforced the government's lack of a credible antiinflation policy and accentuated the falling US dollar. Facing crisis, the Carter administration 
proffered a massive scheme to offset the dollar collapse that would involve a sharp increase in interest rates, coordinated intervention to prop up the dollar supported by an international pool of reserves including funds from West Germany, Switzerland and Japan, and the pledge to issue foreign currency-denominated US government debt, so-called Carter bonds (Bordo, Humpage and Schwartz 2015).

This rescue package stabilized the US dollar and financial markets. However, economic performance was deteriorating and a second oil price shock that resulted from a sharp decline in Iranian oil production doubled oil prices and slowed real GDP to fractional growth in 1979. Stagflation--the combination of high inflation and poor real economic performance with rising unemployment-had enveloped the economy. The high inflation and rising unemployment were inconsistent with a downward-sloping Phillips Curve. Policymakers were faced with poor economic performance and policies that required remedy.

Volcker's aggressive disinflation monetary policy. The biggest concern facing policymakers was that reducing inflation would harm the economy and raise unemployment. Many, including Alan Greenspan, Chairman of the Council of Economic Advisors under President Ford, advocated a more gradual monetary tightening while Paul Volcker argued that aggressive tightening was required to reduce inflationary expectations. He made clear those intentions to President Carter who nominated him to become Fed Chairman and in his confirmation hearings before the Senate (Volcker 1979). In October 1979, when inflation was nearly $12 \%$, the Volckerled Fed began its aggressive anti-inflation monetary tightening.

Through April 1980, the Fed raised interest rates from $11.5 \%$ to $17.6 \%$ and slowed money growth. Concerned with inflation and excessive use of credit, President Carter tried to restore discipline through credit controls on consumers and technical tax policy adjustments that would raise government tax receipts. Carter's actions backfired, as many consumers believed that he had put a ban on credit card purchases, which generated a deep recession in the second quarter of 1980. 
The Fed backed away from its monetary tightening, lowering interest rates to 9\% in July 1980. When economic growth resumed, the Fed more than doubled rates to $19 \%$ by early 1981 , generating a marked deceleration in money growth. The Fed maintained its restrictive monetary policy through June 1982.

President Reagan entered office in January 1981, and the Economic Recovery Tax Act of 1981 dramatically lowered taxes while government spending was increased, nearly exclusively for defense. Recession persisted through year-end 1982, in response to the restrictive monetary policy and adjustment to lower inflation. Inflation receded below $9 \%$ by December 1981 and to 3.8\% by December 1982. Inflationary expectations adjusted to the new monetary regime while the fiscal policies set the stage for stronger growth. The US dollar strengthened dramatically. Even as the real economy rebounded, with robust real GDP growth averaging 6\% in 1983-1984, inflation remained below 4\%, its lowest sustained rate since 1967.

Volcker's strategy hinged critically on the Fed's credibility to impose a persistent monetary policy that would achieve low inflation (Bordo, Erceg and Levin 2017). Critics and public outcries were loud, but the Volcker-led Fed persisted. The Fed received full support from President Reagan.

Volcker's successful disinflationary monetary policy ushered in the Great Moderation, a sustained period of moderate inflation, economic expansion and prosperity. The lessons learned from Volcker's policies are historic.

\subsection{Monetary and Fiscal Policy Interactions in the Great Inflation in the UK 1965 to 1980}

The inflation performance of the UK was considerably worse than the G10 average. Inflation peaked in 1980 at 25\% versus the US at $13.5 \%$. Bordo, Bush and Thomas (2020) argue that the UK experience can best be characterized as one of fiscal dominance under which fiscal deficits by the Treasury (referred to as the Public Sector Borrowing Requirement, PSBR) was accommodated by the Bank of England (which at the time was not independent from the Treasury). 
Two deep fundamentals that underlay the UK experience were: first adherence to the pegged (adjustable) exchange rates (and the capital controls) of the Bretton Woods System (Bordo 1993). Under the BWS once the UK declared current account convertibility in December 1958, financial (monetary and fiscal) policy was constrained by the pegged exchange rate and the state of the balance of payments. The expansionary fiscal/monetary policy leading to a rise in nominal income (referred to as Go policy) would lead to a balance of payments (current account) deficit reflecting an increased demand for imports, a decline in international reserves and often a speculative attack on the pound (a currency crisis). The crisis would then be resolved by a rescue by the IMF, G10 leading to a policy of contractionary fiscal/monetary policy (Stop policy). This would continue until nominal income had contracted sufficiently to remove the deficit and replenish international reserves (see figure 13).

A second fundamental was that the real growth of the UK economy and the growth of productivity were lower than its trading partners. These factors contributed to overvalued nominal and real exchange rates, which in the presence of the peg led speculative attacks and currency crises. These forces led to contractionary effects on the British economy and created reasons for fiscal and monetary policies to offset them.

A final important factor was the role of the trade unions who strongly resisted downward wage movements and made it difficult for the monetary authorities to follow tight financial policies. This helped create a ratchet in the inflation rate.

\subsection{Active Fiscal and Passive Monetary Policy in the 1960s}

The UK Treasury generally followed expansionary policies in this period. It ran persistent and rising deficits that were mostly accommodated by expansionary Bank of England policies. There were a number of justifications for these policies. The first was the belief in the efficacy of Keynesian aggregate demand management policies to offset business cycle fluctuations and to maintain full employment. Keynesian thinking dominated the Treasury, the Bank and the government as a whole. Related to this was the Phillips curve tradeoff that a reduction in the unemployment rate could be accomplished at the expense of higher inflation. Second, it was 
believed that expansionary aggregate demand policies would not only reduce the output gap but would also raise the long-run growth rate and even reduce the inflation rate. This view associated with the work of Nicholas Kaldor (1966) posited that expansionary fiscal policy would raise investment and in turn the growth of technical change and the capital stock. The rise in growth in turn associated with increasing returns to scale in industry would both raise real wages and reduce inflation. Empirical estimates and forecasts of the British growth rate in the 60 s by the National Institute of Economic and Social Research (NIESR) justified this "Going for Growth Strategy" Estimates of potential annual growth rates of 6\%, were way above the historical trend growth rate of $2.5 \%$. A final important rationale for expansionary fiscal policy was to improve the living standards of labor. The idea had several strands that were accepted by both the Conservatives and Labour parties. First was the power of the trade unions who continually pushed for higher wages and for redistribution from capital to labor. Second was the fear of social unrest should living standards decline, as was perceived to have been the case in the interwar period. This there was a postwar consensus for full employment and for sustained real growth.

A serious problem with these views is that they conflated aggregate demand with aggregate supply. British policy makers continued to believe that aggregate demand policy could stimulate the economy and also increase the underlying growth rate.

The BWS period from the late 1950s until the breakdown of Bretton Woods can be characterized by Go-Stop policy (Dow 1964). To maintain full employment and raise growth rates, successive government of both parties pursued expansionary fiscal policy (increasing government expenditure and reduced taxes (see figure 14) which in turn were accommodated by expansionary monetary policy. These expansions, which lasted 2-3 years, always ended when the economy hit the balance of payments constraint. On several occasions $(1959,1961$, $1964,1967)$ this led to a speculative attack on the Bank's international reserves and a currency crisis (see Bordo, MacDonald and Oliver 2009), which required rescue loans from the IMF, G10, BIS and the Federal Reserve. Once reserves were restored, pressure increased on the government to fiscally expand and the economy would transit again into the Go phase. During the Go phase not only would the economy recover but prices would rise and as the 60s 
progressed inflation became a growing problem. Moreover, as inflation increased so did inflationary expectations. This meant that after each successive stop period the underlying inflation rate would be reduced but not entirely. This led to an upward ratchet in the inflation rate as the monetary authorities renewed expansionary policy.

A key belief in the 1960s and 1970s in the UK and later the US was that inflation was not caused by expansionary aggregate demand, especially by expansion in the money supply as was argued by Milton Friedman and the monetarists. Rather, it was caused by cost-push forces-the increasing power of trade unions to raise wages and the increasing power of industry to push prices up to keep up with the rise in wages, leading to a wage price spiral (DeCeccio and Nelson 2013).

The solution to the cost-push problem was to impose incomes policies: wage price guidelines, and later wage price controls. It was not understood that wage price controls would only make the problem worse by creating suppressed inflation, which distorted the real economy. As Milton Friedman once stated "suppressed inflation was like filing a kettle with water, putting it on the stove and turning on the burner and ten putting a brick on top of the kettle."

The Go stop policies of the 1960s turned into a hyper-Go phase after the collapse of the BWS in 1971-72. Now the imperative to "Go for Growth" was no longer hobbled by the balance of payments constraint and so Go fiscal policy accommodated by expansionary monetary policy went into overdrive. The best example of this was the Barber boom of 1971 to 1973. In 1973, the monetary authorities attempted to reduce the accelerating inflation by raising interest rates and the Treasury reducing government expenditures. But it was short-lived.

The boom ended with the first oil price shock in late 1973, which led to a downturn in the real economy. However, the oil price shock was accommodated in 1974 by expansionary financial policies and the Go phase returned. The policies to raise aggregate demand to offset the decline in real income associated with a change in the relative price of oil led to a decline in the exchange rate, declining international reserves and increasing inflation.

The Go Phase of inflation led to a massive run up in prices to $25 \%$ per year by 1975 and a severe drop in the exchange rate. This led to a new sterling crisis in 1976 precipitating an IMF mission that urged the monetary authorities to reduce domestic credit and the budget deficit (Roberts 
2017). This external intervention was the catalyst that led officials in the BOE to pay more attention to the behavior of the monetary aggregates and the monetarist views of Friedman, Brunner and Meltzer that inflation was a monetary phenomenon that could only be contained by monetary contraction.

The Great inflation continued through the 1970s, reaching a peak in 1980 of $18 \%$ as a result of the end of exchange control and a surge of bank credit expansion (James 2020 page 83). As in the U.S, the Great Inflation ended consequent upon a major regime change in 1979-1980 when Margaret Thatcher came to power and applied the monetarist medicine. Led by Alan Walters, her special advisor, the Treasury put in an ambitious plan to both reduce fiscal deficits by cutting expenditures and raising taxes and by having the Bank adopt the monetarist recipe of monetary targeting of broad money (sterling M3) and significantly reducing money growth (See figures 13 and 15).

The strategy, similar to that followed by Paul Volcker in the U.S., was very successful in reducing both inflation and inflation expectations considerably by 1983 and ending the Great Inflation in the UK. As in the US, the disinflation was accompanied by a decline in real GDP and a rise in unemployment.

\section{Recent Episodes}

The Great Financial Crisis (GFC) of 2008-2009 and the pandemic of 2020 are two modern episodes of surges in deficit spending that illustrate the linkages between deficits and inflation. Both involved high budget deficit spending and easy monetary policies. This section reviews the policies around the GFC and identifies the important factors why the spike in deficit spending and the Fed's unconventional monetary easing did not generate higher inflation. It then analyzes the differences in macroeconomic responses to the pandemic, which may raise the risks of higher inflation. The section concludes with a brief discussion about how the government's rising debt may impinge on the Fed's monetary policy and a possible rising risk of fiscal dominance.

\subsection{The Great Financial Crisis 2007-2008}


In the years preceding the GFC, there were persistent deficits and inflation rose above the Fed's $2 \%$ objective. President George W. Bush campaigned as a fiscal conservative but cut taxes in response to the recession of 2001 and the 9/11 attacks and increased spending. Early in the expansion, from 2002- 2004, the Greenspan-led Fed was excessively concerned with the possibility of deflation, and maintained easy monetary policy, keeping its policy rate below the rate of inflation. This facilitated the environment for the debt-financed boom in housing (Taylor 2007). Inflation and inflationary expectations rose and the US dollar depreciated.

The Fed's gradual but persistent policy rate increases contributed to a reversal in the debtfinance booming housing market beginning in spring 2006. This depressed expectations and generated sizable losses in mortgage-backed debt securities and complex derivatives. A shift toward risk aversion damaged short-term funding markets in fall 2007, requiring a liquidity infusion by the Fed, and mounting financial stresses followed.

Fiscal and Monetary Responses to the GFC. Besides the Fed aggressively lowering its interest rates from 5.5\% in October 2007 to $1 \%$ in November 2008, the government was slow to respond to the increasing signs of financial stresses. Dysfunctional financial markets and severe risk aversion in late 2008 finally elicited coordinated responses from the Treasury, Federal Reserve and Congress.

Congress enacted the Emergency Economic Stabilization Act of 2008 that authorized financing of the Treasury's Troubled Asset Relief Program (TARP) that provided $\$ 700$ billion, or $4.8 \%$ of GDP, of capital infusions into the largest banks through purchases of toxic assets.

The Fed initiated its first round of quantitative easing (QEI) in November 2008, primarily purchases of mortgage-backed securities (MBS) aimed at the dysfunctional mortgage market. Fed Chairman Bernanke emphasized that QEI was "credit policy" because it focused on MBS, and stated that the Fed would unwind its purchases "on a timely basis" in order to reduce inflation risks (Bernanke 2008)

This was followed by the Economic Recovery and Jobs Act (ERJA), a fiscal stimulus package of $\$ 780$ billion in deficit spending that was signed into law by President Obama in January 2009. The combined government spending and emergency loans of ARJA and TARP, approximately 
$10.3 \%$ of GDP, is far less than spending increases during major wars, but was the largest peacetime spending since the Great Depression of the 1930s.

The Fed initiated QEII in March 2009, which involved more purchases of MBS and also Treasuries. This was followed by a Fed maturity extension program, so-called Operation Twist, of selling short-term Treasuries and buy longer-term Treasuries, which lengthened the duration of its portfolio holdings in an effort reduce bond yields. It was largely considered ineffective, having little sustained impact on bond yields (Ehlers 2011).

In 2012, amid moderate economic growth but a lingering high unemployment rate, the Fed initiated QEIII, open-ended asset purchases of Treasuries and MBS. QEIII continued through October 2014, raising the Fed's balance sheet to $\$ 4.5$ trillion from its average of $\$ 900$ billion balance prior to the GFC. The Fed anchored interest rates to zero until the end of 2015.

Inflation concerns following the financial crisis. Even in the initial stages of recovery from the deep recession, when the unemployment rate hovered around 10 percent, there were concerns that the surge in money supply stemming from the Fed's unconventional QEs ballooning balance sheet and sustained zero interest rates would lead to higher inflation. At the same time, soaring deficits were a worry. Government debt rose to $91 \%$ percent of GDP, the highest since World War II (figure 15), and the Congressional Budget Office forecast significant further in rises in in its long-run projections (CBO 2010), reflecting the aging population and higher costs of Medicare and Medicaid.

Why didn't inflation rise? In the decade of sustained economic expansion that followed the GFC, inflation remained low and fears of rising inflation dissipated. By decade-end, with the unemployment rate at a 50-year low, the Fed expressed concern that inflation was too low (Powell 2019). Numerous factors may explain the constrained inflation. The primary reason why inflation stayed low is that the unprecedented monetary easing, including the Fed's massive balance sheet and sustained zero interest rates, and the record deficit spending, did not stimulate any sustained acceleration in aggregate demand (Levy 2017). This constrained excess demand and product pricing and wages. 
The monetary base (MB)-bank reserves plus currency--grew over $100 \%$ in response to the Fed's QEI and 25\% with QEII and QEIII, but M2 growth picked up only modestly and temporarily in response to QEI and then decelerated significantly (figure 16). In effect, the Fed's QEs increased the supply of bank reserves, but banks increased their demand for reserves rather than providing credit to the economy. There was little if any influence on broader money growth, credit lending or aggregate demand. Thus, the money multiplier (M2/MB), the relationship between the Fed's high-powered money and broader money supply, collapsed (figure 17). At the same time, money velocity (NGDP/M2) receded as the demand for money rose as an adjustment to lower interest rates ${ }^{14}$. The economic responses to the 2009 fiscal stimulus was also modest. Some observers attributed the lackluster response to the poor structure of the fiscal initiatives within the ARJA (Feldstein 2011).

Even with the massive Fed response to the financial crisis, nominal GDP averaged just 3.8 percent during 2010-2013. This resulted in 2 percent real growth and 1.8 percent inflation. Subsequently, during the four years following the Fed's QEIII and sustained zero interest rates, nominal GDP growth did not accelerate, averaging 4 percent (Levy 2018). Over the decade, from 2010-2019, nominal GDP averaged 4 percent, with 2.25 percent real growth and 1.75 percent inflation.

The Fed's easy monetary policy may not have generated stronger economic activity because of a combination of risk averse behavior by banks and the non-financial sector and changes in some of the Fed's operating procedures and regulations that may have created bottlenecks in the monetary transmission channels (Jordan 2016 and Nelson 2020). The Fed began paying interest on excess reserves in October 2008, which reduced the cost of holding reserves and deterred lending (Ireland 2020). It changed from managing the effective funds rate through a

\footnotetext{
${ }^{14}$ See Anderson, Bordo and Duca (2017) who compare the drop in velocity in the 1930s with the GFC. Velocity recovered after World War II reflecting a reduction in uncertainty, financial innovation and rising interest rates, whereas in the aftermath of the GFC it did not snap back for close to a decade after the crisis ended. Their model of the long-run behavior of M2 velocity finds that raised levels of uncertainty (seen in measures of the liquidity premium) associated with the Dodd Frank Act of 2010 is a key determinant of the slow bounce back in velocity.
} 
corridor system to a floor system, which dramatically changed the conduct of short-term funding markets and expanded the Fed's role. Following the GFC, risk averse banks-particularly big banks that faced the Fed's stress tests and intense credit reviews--tightened credit standards and constrained credit. According to Federal Reserve data collected from commercial banks, bank commercial and industrial (C\&I) loans fell significantly from Sept 2008 through Dec 2010 and did not regain prior levels until late 2014, while consumer loans fell even more, not regaining their prior peak until Q1 2016 (Federal Reserve 2020).

The weak aggregate demand growth fell shy of expectations laid out by Fed Chair Bernanke and forecasts by the Fed's FRB-US macroeconomic model, which projected strong growth and higher inflation (Bernanke 2012). Although asset prices were pumped up and risk-taking flourished there was little pickup in growth of M2 or nominal GDP (Levy 2017). The moderate economic growth that did occur lowered unemployment but constrained inflation. Inflationary expectations receded, reinforced by the non-acceleration of wages.

The low inflation became an increasing concern for the Fed which worried that if sustained it could lead to a downward spiral in inflationary expectations, which with the zero lower bound on interest rates would constrain the Fed's ability to fight a future economic downturn. However up to then stable low inflation had been associated with sustained economic expansion, and inflationary expectations had remained fairly closely anchored to $2 \%$. During the decade, inflation in the UK, Europe, Japan and other advanced nations remained low, and global central banks expressed the same concerns as the Fed about low inflation.

\subsection{The Pandemic of 2020.}

On the eve of the pandemic, the Fed's balance sheet was enlarged and its policy rate was low, and budget deficits were high and government debt was projected to rise sharply. The pandemic and mandated government shutdown generated a deep economic contraction, with real GDP plunging 9\% in the second quarter 2020, the fastest in history. In March, risk premiums and volitility spiked in financial markets as the stock market fell dramatically, yield spreads of corporate bonds and other debt instruments soared and the U.S. treasury market 
became temporarily dysfunctional. The government responded with unprecedented monetary and fiscal stimulus.

Fiscal initiatives, which included the CARES Act, involved approximately $\$ 3$ trillion in new deficit spending, or $13 \%$ of GDP. The Fed promptly lowered its policy rate to zero, purchased over $\$ 2$ trillion of Treasury securities and MBS, provided short-term liquidity and purchased corporate and municipal bonds and made direct loans to businesses. In less than two months, the Fed had increased its balance sheet from $\$ 4.5$ trillion to $\$ 7$ trillion.

The government's responses were similar in certain ways to wartime in magnitude and initiatives that harnessed and redirected private sector resources to combat the pandemic. Unlike many wars, taxes were not increased, so all of the increases in government spending were debt-financed.

The contractionary economy and insufficient aggregate demand temporarily eased inflation (Levy 2020), but some have argued that there may be risks of higher long-run inflation (Goodhart 2020).

In striking contrast to monetary policy during and following the GFC, both the monetary base and M2 have surged (Levy 2020). During March-May 2020, while the Fed's QE and increase in supply of bank reserves increased the monetary base $51 \%$, and its year-over-year rise through September was 50.2\%. M2 rose 20.2\% during March-September, lifting its year-over-year rise to $24 \%$. Risk averse businesses drew down unused lines of credit from their banks and left them as deposits counted in $M 2$, also generating a surge of $C$ and I loans (figure 18). This business risk aversion partially reversed over the summer. Household saving and bank deposits soared, reflecting the "forced" consumer saving by the pandemic and government shutdowns and the sizable portion of the government's generous income support fiscal policy that was saved.

The aggressive monetary and fiscal actions appeared to have supported the economic recovery in the third quarter of 2020 (Edelberg and Sheiner 2020 and Powell 2020). The simultaneous surges in bank deposits and the rate of personal saving (refected in a drop in the income velocity of money of several monetary aggregates) suggest that a significant amount of 
deferred consumer purchasing power remains at the end of 2020, and may be spent as the risks and fears of the pandemic abate, boosting aggregate demand (figure 19).

The Fed's new strategic framework. In response to its fears of low inflation and the zero lower bound, the Fed adopted a new strategy that explicitly favors higher inflation and views higher inflationary expectations as an important aspect of achieving its new objective (Powell 2020 and Clarida 2020). This strategy involves an asymmetric flexible average inflation targeting (FAIT) that involves a makeup strategy of higher inflation following a period of sub-2\% inflation and employment mandate of "maximum inclusive employment", that emphasizes "shortfalls" rather than "deviations" from the maximum (Powell 2020). This reinterpretation of its dual mandate and the Fed's signal that it would not tighten preemptively in response to higher anticipated inflation it has been argued may pose risks of higher inflation (Levy and Plosser $2020)$.

Under this monetary regime, any future reduction in productivity and potential growth could add to inflation pressures. The economic environment of the 1970 s provides a warning. Then, stagflation resulted from sustained monetary ease and double-digit growth of aggregate demand while tax and regulatory policies distorted economic behavior and constrained potential growth.

Risks of fiscal dominance and influences on monetary policy. Some have argued that the rising fiscal deficits and debt since the Covid 19 pandemic began in March 2020 may possibly impinge on monetary policy in the future. Sustained deficits may raise the risk of fiscal dominance, as we have seen in the past (Sims 2020). This could occur along several dimensions. First, the massive deficits and Treasury bond issuance contributed to financial instability in March 2020 that led the Fed to come to the rescue. The jump in Treasury bond issuance in midMarch 2020 associated with a spike in the government's cash flow deficit, combined with abrupt selling of treasuries, squeezed the balance sheets of the primary dealers in treasuries and resulted in illiquidity and dysfunction in the treasury market (Duffie 2020). The Fed intervened, purchasing over $\$ 1.5$ trillion of Treasuries in a six week period and easing capital 
requirements of primary dealers. Some argue that persistent high deficits and Treasury bond issuance may raise the risks of future problems. Boskin (2020) and others expressed concern that without support from the Fed the domestic and foreign demand for Treasuries ultimately may become inelastic, and a curtailment of demand may drive up yields.

Second, although there is no evidence or any indication that the Fed has taken into consideration the impacts of its policies on government finances, the increased sensitivity of debt service costs to interest rates (CBO 2020) highlights the importance of Fed policies. At its June 2020 FOMC meeting the Fed signalled that it would anchor its policy rate to $0 \%$ through 2023 and that it would continue purchasing Treasuries and MBS. The Fed has been aware that its policies are widely considered a factor that has kept bond yields low, and it is careful to avoid policy changes that may jar financial markets (Federal Reserve 2020).

Third, the Fed's independence from the fiscal authorities may also be jeopardized by Congress's ability to tap the Fed's massive asset holdings or the net profits it remits to the Treasury to finance future expenditures. Fiscal legislation to replenish the Highway Trust Fund in December 2015 established a precedence for such action. The Fed currently holds $20 \%$ of total publiclyheld debt and it pledges to purchase an additional new $\$ 80$ billion in Treasury securities per month, approximately the equivalent of $60 \%-70 \%$ of new deficits during $2021-2023$. There is evidence that some members of Congress view the Fed's massive balance sheet and the net profits it remits to the Treasury as possible sources of funding (Levy 2017). Indeed some have argued that Congress may appropriate funds from the Fed without any legal recourse (Plosser 2018). Moreover, some have argued that the Fed's new programs to purchase corporate and municipal bonds (Bordo and Duca 2020a and 2020b), and to make direct loans to businesses, have thrust the Fed into credit and fiscal policies that have been traditionally conducted by the Treasury and Congress (Judge 2020 and Gilchrist et al 2020).

Goodhart and Pradhan (2020) argue that pressures for more deficit spending may continue to mount in the future, reflecting demographics, social pressures stemming from income and wealth inequality, the need to upgrade infrastructure, and other demands. They anticipate that these demographic and fiscal pressures will boost aggregate demand while constraining aggregate supply, ushering in an environment of higher inflation. 
The pandemic has elicited activist fiscal and monetary policies in the U.S. and other countries.. The CBO projects persistent deficits and sharp increases in government debt under current law (CBO 2020). Whether persistent fiscal deficits alone without monetary accommodation is inflationary, as posited by the fiscal theory of the price level, is an open question. US budget realities in the light of the pandemic and the lessons from history highlight the future risks of fiscal dominance.

\section{Conclusion: Some Lessons for Policy}

We posed the question, under what circumstances do increased fiscal deficits lead to inflation? Our historical survey of key advanced countries leads to the conclusion that the state of nature-war or peace--is a key determinant of the connection between fiscal deficits and inflation. Our survey of the history of major wars shows how inflationary finance was developed in the eighteenth century and became an important component of war finance. Early central banks like the Bank of England were established expressly to aid the government's military aims. Beginning with the Napoleonic wars, the Bank of England aided the government's war aims by freely discounting Treasury bills and the commercial paper of private agents providing war material.

In the US, limitations to government 's ability to tax and to issue debt led to the issuance of continentals and greenbacks. In the world wars of the $20^{\text {th }}$ century, the central banks pegged short-term and long-term rates to aid the Treasury's funding. Setting the central bank's discount rate below the natural rate encouraged private sector borrowing and, in a Wicksellian manner, led to commercial bank note expansion.

Fiscal deficits have been long associated with monetary finance in emerging countries with underdeveloped financial systems and weak fiscal administration and the issue of fiat money. This was long condemned by classical monetary doctrine. We describe several cases in advanced countries in which peacetime fiscal deficits were associated with unbacked fiscal expansion and dominance of the central bank by the fiscal authorities: France in the 1920s, when paralysis in governance led to the Banque de France freely absorbing the government's 
short-term debt and issuing fiat money; the US in the 1930s, after FDR left the gold standard, and pursued aggressive unbacked fiscal expansion; and the U.S. and UK in the 1960s-1970s, when the central banks accommodated the expansionary fiscal policies with loose monetary policies fueling inflation.

Two key factors seem to lie behind the peacetime adoption of fiscal dominance: political dysfunction/political pressure and flawed doctrine. In the 1920s, the dysfunctional French government could not agree on how to finance its expenditures, by default leading to the Banque de France's printing press. In the 1960s, the Martin-led Fed was pressured by LBJ to avoid contractionary policy, while in the early 1970s Arthur Burns gladly accommodated Nixon's demands. In the UK, fear of union disruption was a key force in its Go stop policies. In both countries, Keynesian views and belief in the Phillips curve tradeoff gripped the policymaking debate, and that inflation was generated largely by cost-push forces and not expansionary monetary policy, and could only be offset by incomes policy. In the UK, there was a belief that expansionary financial policy could raise the growth rate.

The Great Inflation was ended by the successful tight monetary policies of Volcker-Thatcher in 1979-1982 that led the way to the Great Moderation-20 years of moderate inflation and generally healthy economic performance. Central banks gained their independence and pursued flexible inflation targeting strategies that gained credibility.

Since the Great Moderation it seemed unlikely that advanced country central banks would willingly run high inflation policies. Expansionary monetary policy prevailed during and after the GFC, yet for the reasons we describe, inflation remained subdued. During the pandemic, central banks have shifted to highly expansionary policies as fiscal authorities have implemented record-breaking deficits that have pushed debt ratios close to WWII levels (and beyond in the US). Currently, inflation in the US is well below the Fed's $2 \%$ target. What are the risks that could trigger moderate or even high inflation?

One possibility is that the unprecedented peacetime deficits and monetary accommodation raise the risks of sustained (money growth fueled) excess demand. Also the Fed's new strategic goal of raising inflation may inadvertently run the risk of unanchoring inflationary expectations. Second, the mounting debt could exert fiscal dominance over monetary policy. 
The lessons from our historical survey are: avoid war, be cautious of sustained monetary accommodation of fiscal deficits, avoid fiscal dominance, maintain central bank independence, keep inflationary expectations anchored, and pursue pro-growth economic policies. The evidence suggests that ignoring the lessons from history could be at the policy makers' peril.

Figure 1. United States: Government Debt (\% of GDP)

Government Debt-to-GDP ratio, United States

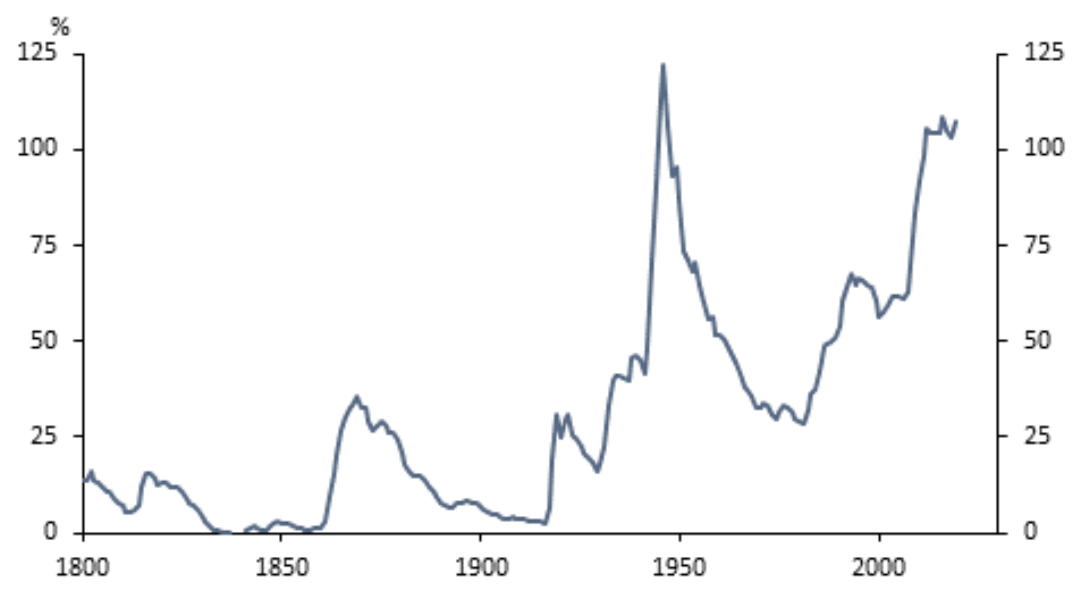

Source: George Hall and Thomas Sargent (2020) "Government Debt and Taxes in Eight U.S. Wars and Two Insurrections" Handbook of Historical Economics. We thank George Hall for providing the data.

Figure 2. United Kingdom: Government Debt (\% of GDP)

Government Debt-to-GDP ratio, United Kingdom

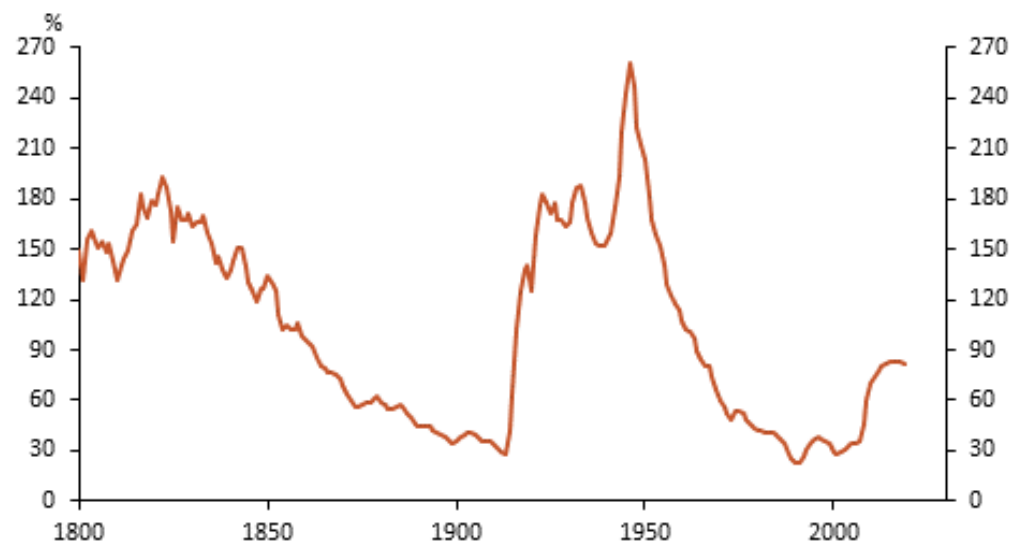

Source: data kindly provided by Ryland Thomas,Bank of England 
Figure 3. Great Britain: Real Deficits (Surplus)

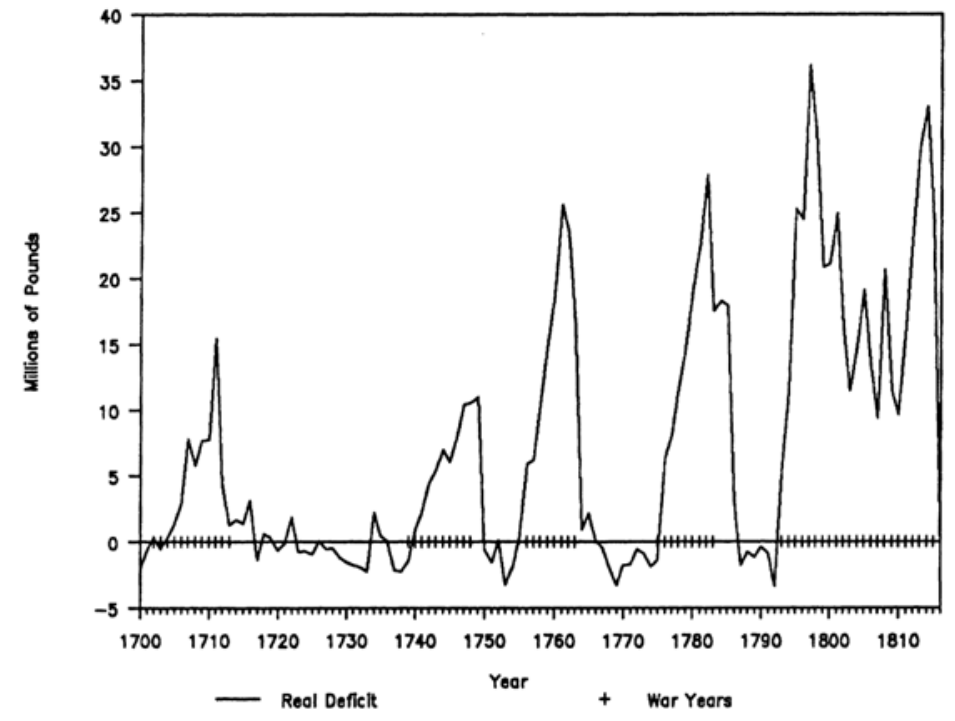

Source: Figure 2 in Bordo, M. D., \& White, E. N. (1991). A tale of two currencies: British and French finance during the Napoleonic Wars. Journal of Economic History, 303-316.

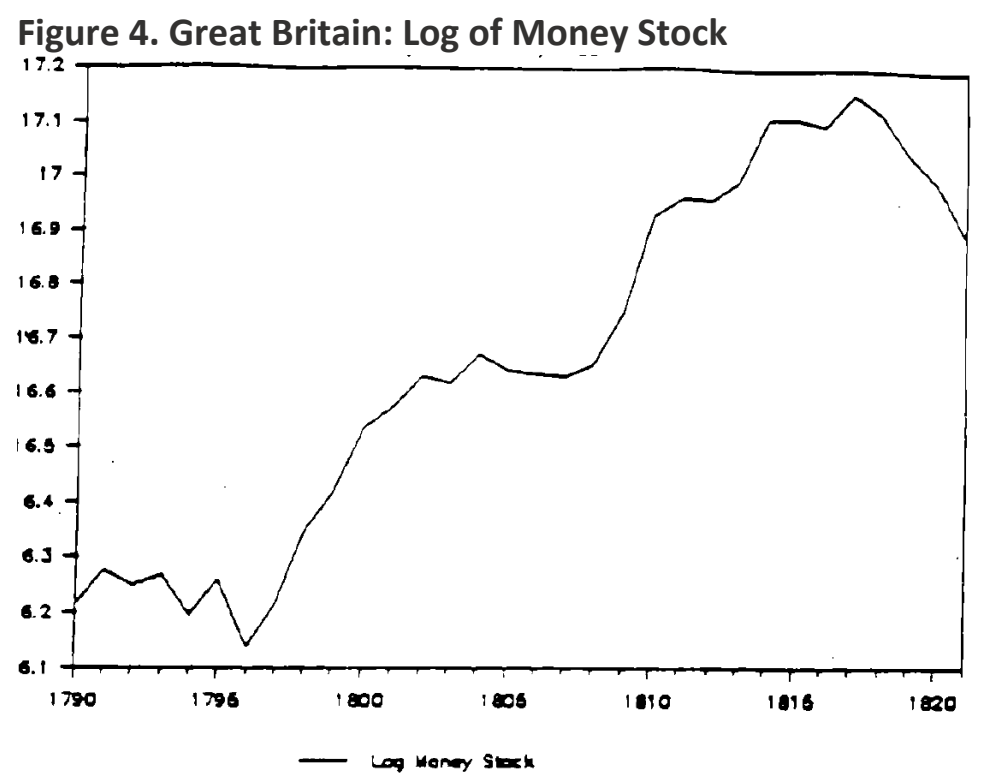

Source: Figure 8 in Bordo, M. D., \& White, E. N. (1990). British and French finance during the Napoleonic Wars (No. w3517). National Bureau of Economic Research. 
Figure 5. Great Britain: Log of the Price Level

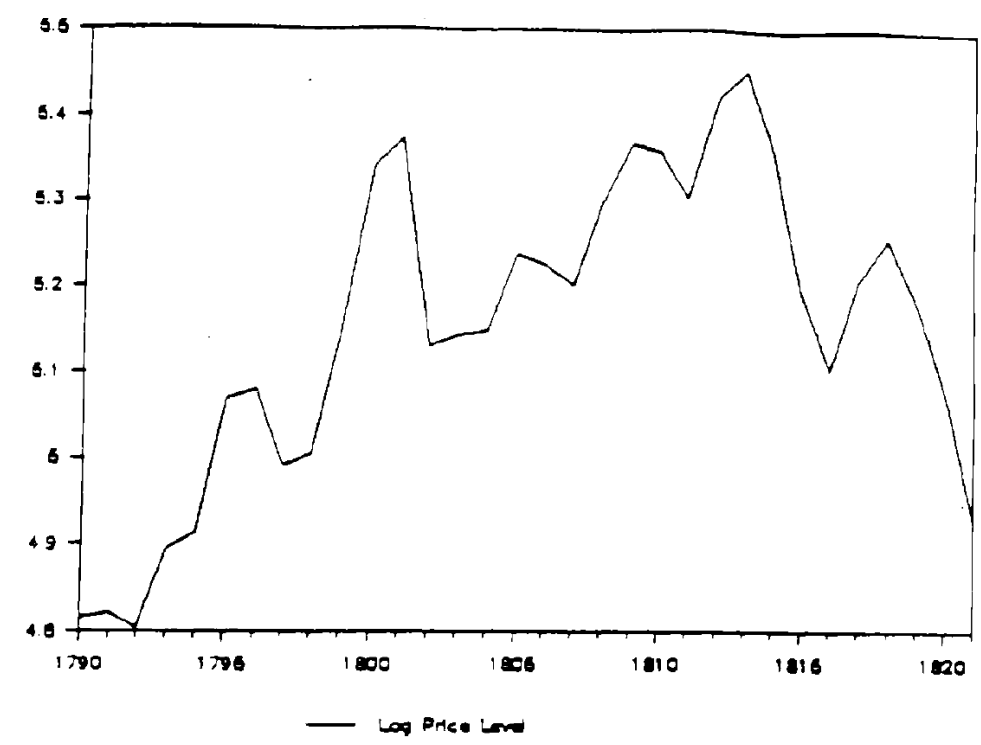

Source: Figure 9 in Bordo, M. D., \& White, E. N. (1990). British and French finance during the Napoleonic Wars (No. w3517). National Bureau of Economic Research.

Figure 6. Price Level $(1910=100)$

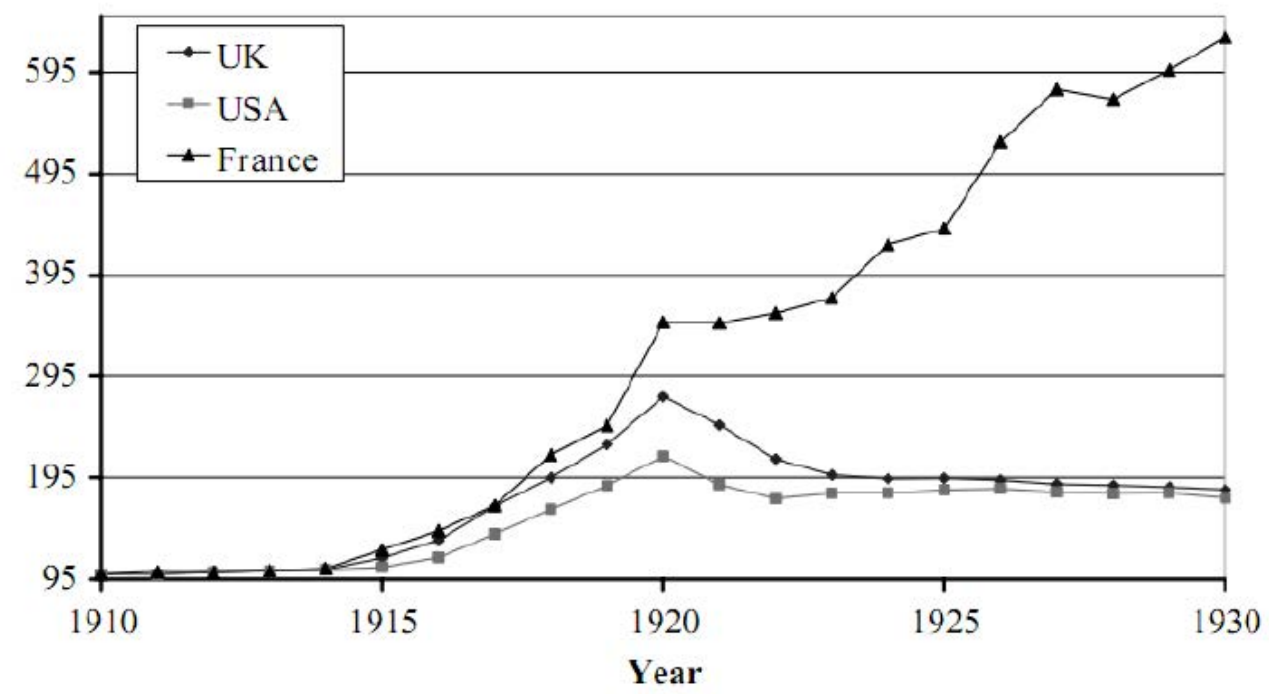

Source: Figure 1 in Comments by Michael D. Bordo in Walker, Todd B. and Leeper, Eric Michael, Perceptions and Misperceptions of Fiscal Inflation (December 1, 2011). BIS Working Paper No. 364, Available at SSRN: https://ssrn.com/abstract=1970290 or http://dx.doi.org/10.2139/ssrn.1970290 
Figure 7. Debt to GDP

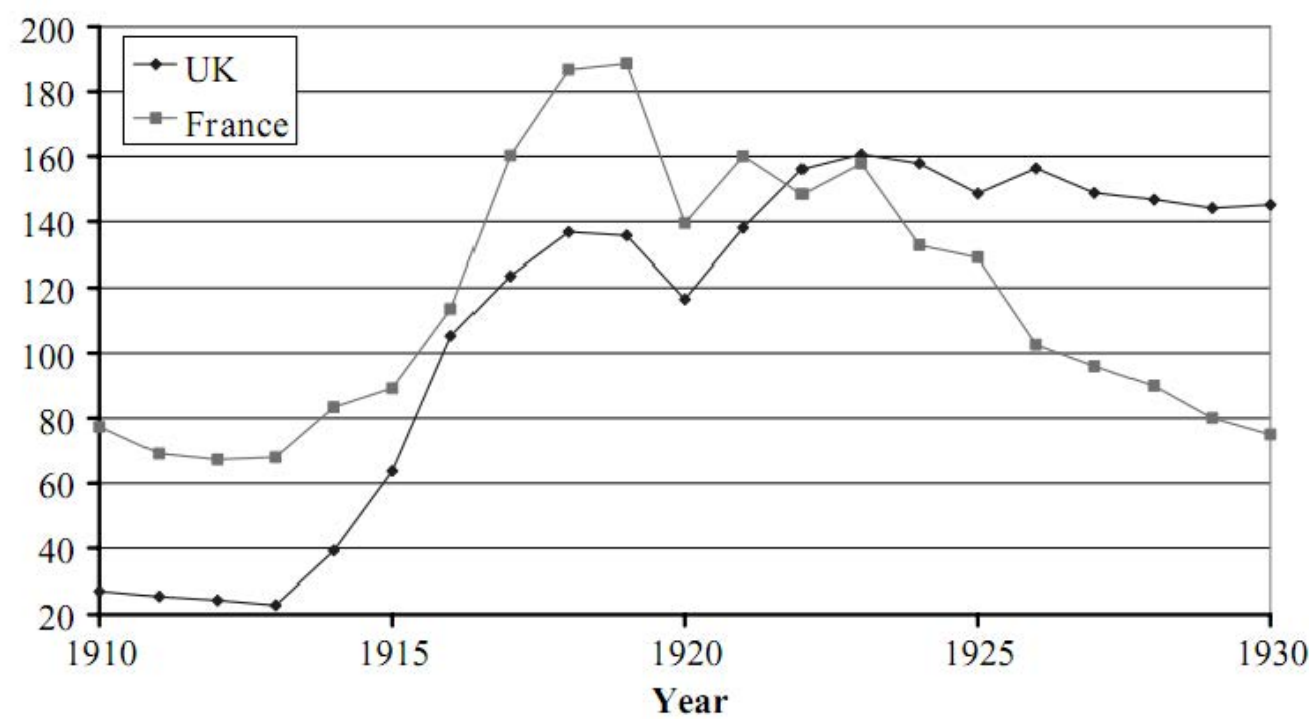

Source: Figure 2 in Comments by Michael D. Bordo in Walker, Todd B. and Leeper, Eric Michael, Perceptions and Misperceptions of Fiscal Inflation (December 1, 2011). BIS Working Paper No. 364, Available at SSRN: https://ssrn.com/abstract=1970290 or http://dx.doi.org/10.2139/ssrn.1970290

\section{Figure 8. Budget Deficit (\% of GDP)}

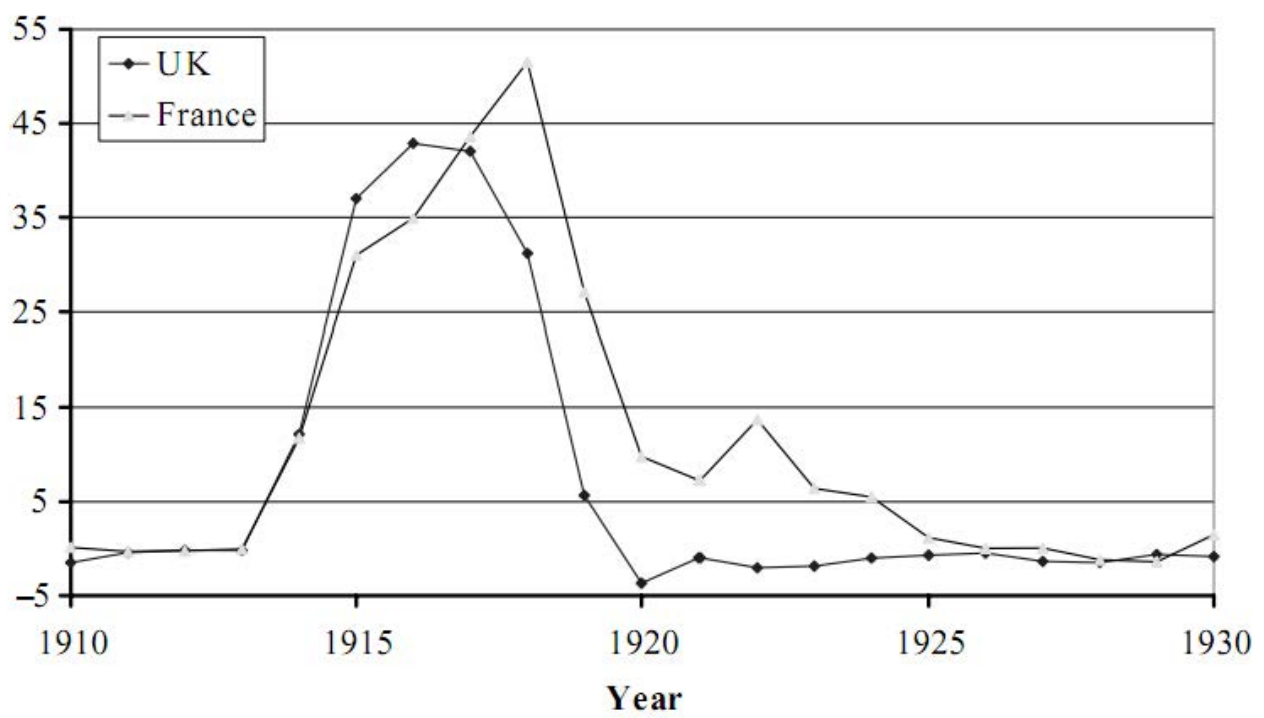

Source: Figure 3 in Comments by Michael D. Bordo in Walker, Todd B. and Leeper, Eric Michael, Perceptions and Misperceptions of Fiscal Inflation (December 1, 2011). BIS Working Paper No. 364, Available at SSRN: https://ssrn.com/abstract=1970290 or http://dx.doi.org/10.2139/ssrn.1970290 
Figure 9. Nominal Exchange Rates

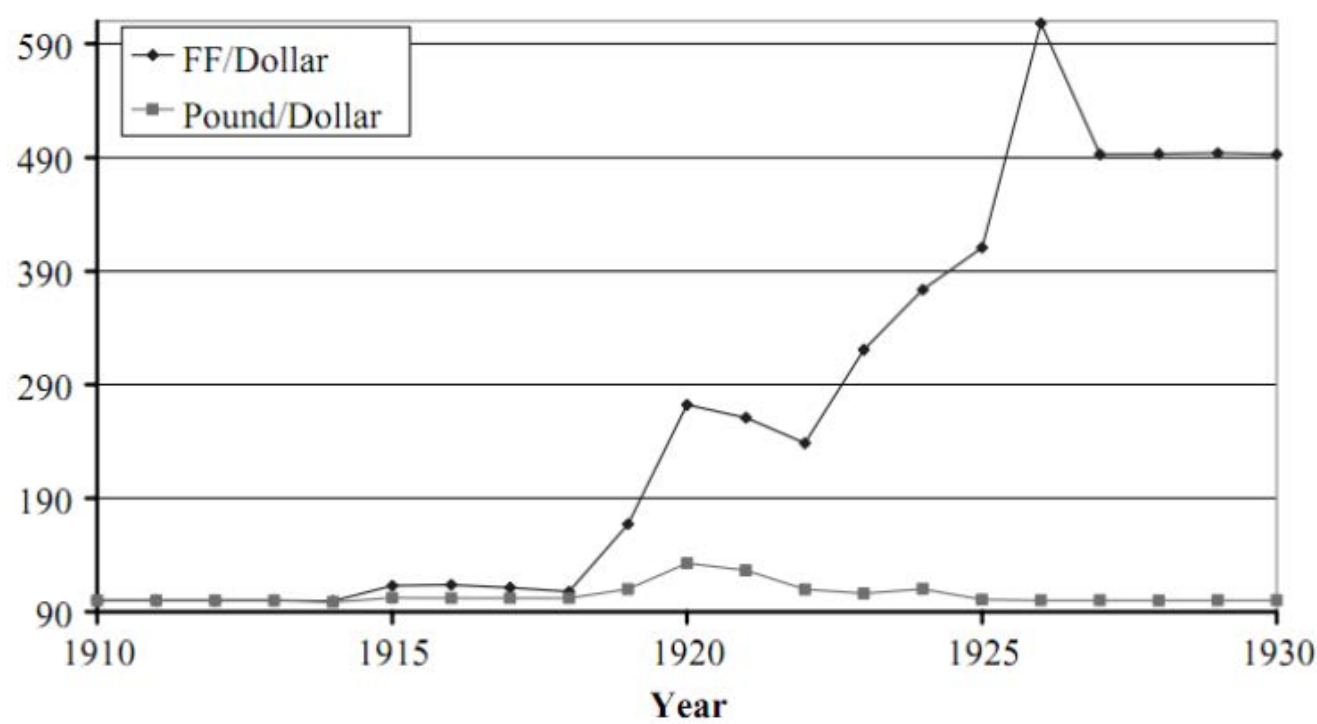

Source: Figure 4 in Comments by Michael D. Bordo in Walker, Todd B. and Leeper, Eric Michael, Perceptions and Misperceptions of Fiscal Inflation (December 1, 2011). BIS Working Paper No. 364, Available at SSRN:

https://ssrn.com/abstract=1970290 or http://dx.doi.org/10.2139/ssrn.1970290

Figure 10. US Budget Balance (\% of Potential GDP)

1

0

$-1$

$-2$

$-3$

$-4$

$-5$

— Primary - federal (\% of potential GDP)

-Full-employment ( $\%$ of potential GDP)

$-6$

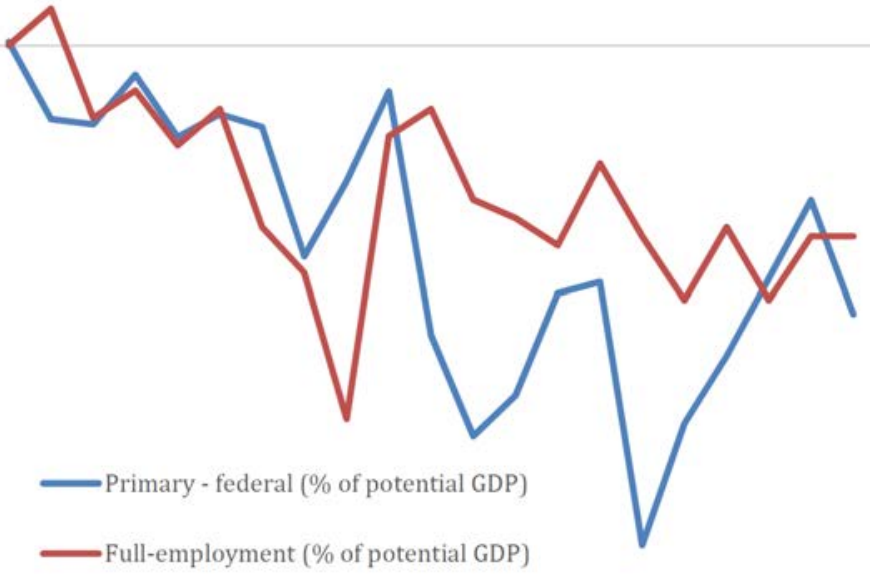

$\begin{array}{lllllllllll}1960 & 1962 & 1964 & 1966 & 1968 & 1970 & 1972 & 1974 & 1976 & 1978 & 1980\end{array}$

Source: Figure 6 in Bordo, M. D. (2020). The Imbalances of the Bretton Woods System 1965 to 1973: US Inflation, The Elephant in the Room. Open Economies Review, 1-17. 
Figure 11. US M2 Growth 1960 - 1982 (\% change)

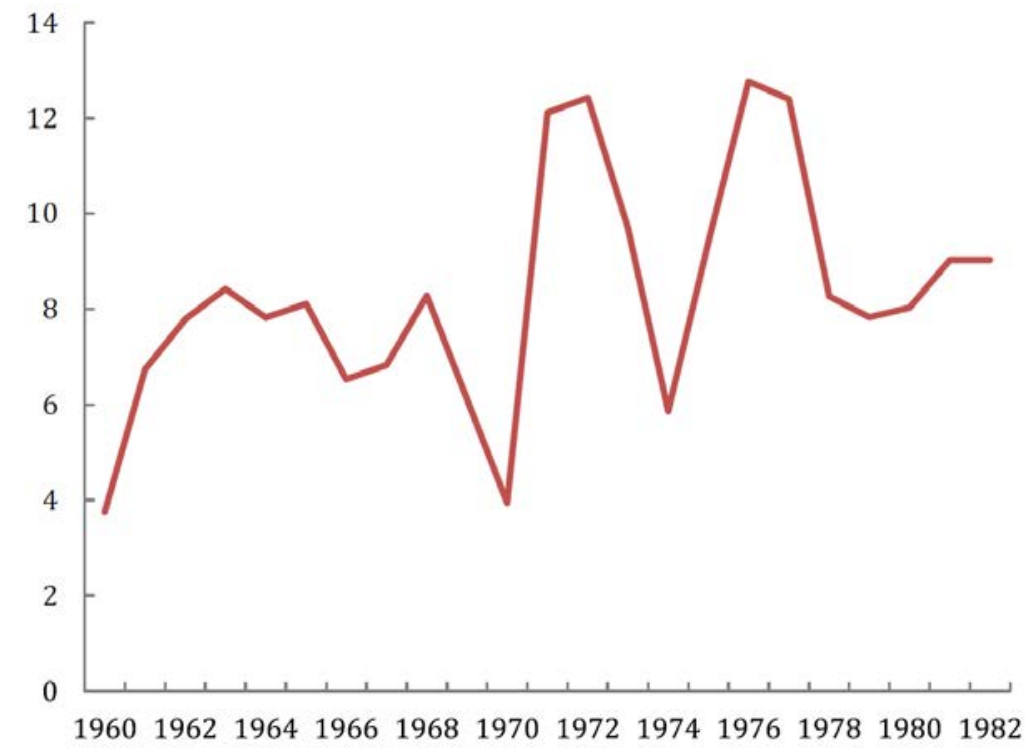

Source: Figure 7 in Bordo, M. D. (2020). The Imbalances of the Bretton Woods System 1965 to 1973: US Inflation, The Elephant in the Room. Open Economies Review, 1-17.

Figure 12. US CPI Inflation 1960 - 1982 (y-o-y \% change)

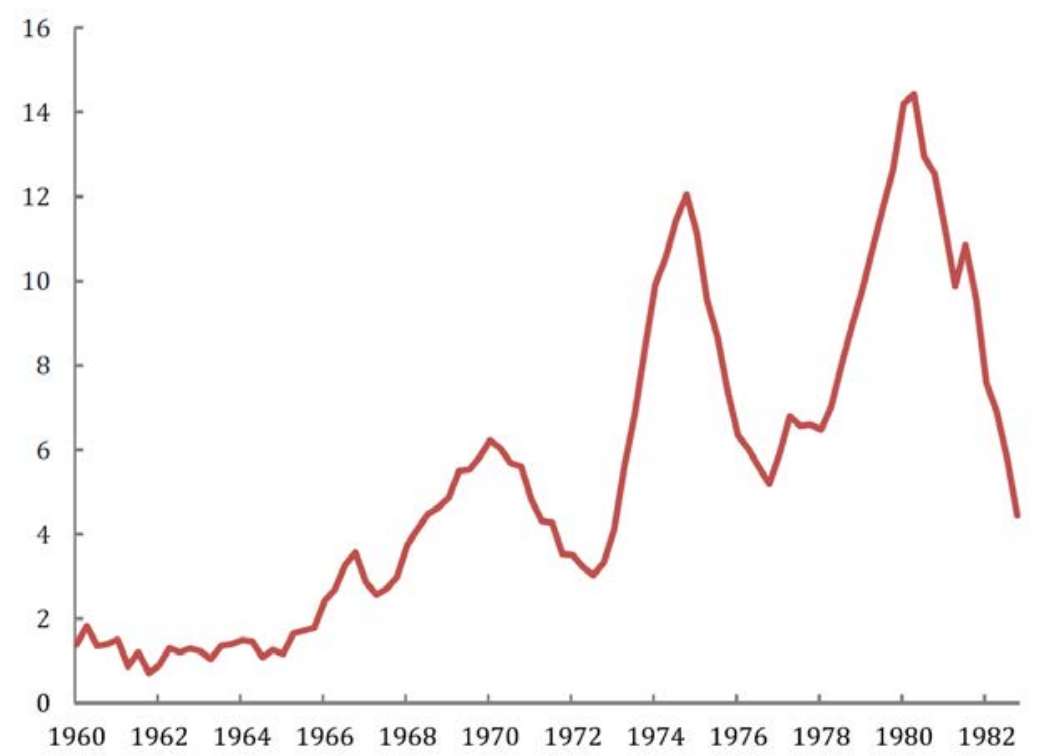

Source: Figure 8 in Bordo, M. D. (2020). The Imbalances of the Bretton Woods System 1965 to 1973: US Inflation, The Elephant in the Room. Open Economies Review, 1-17. 
Figure 13. UK Money Growth and CPI Inflation (\% change on 4 qtrs. earlier)

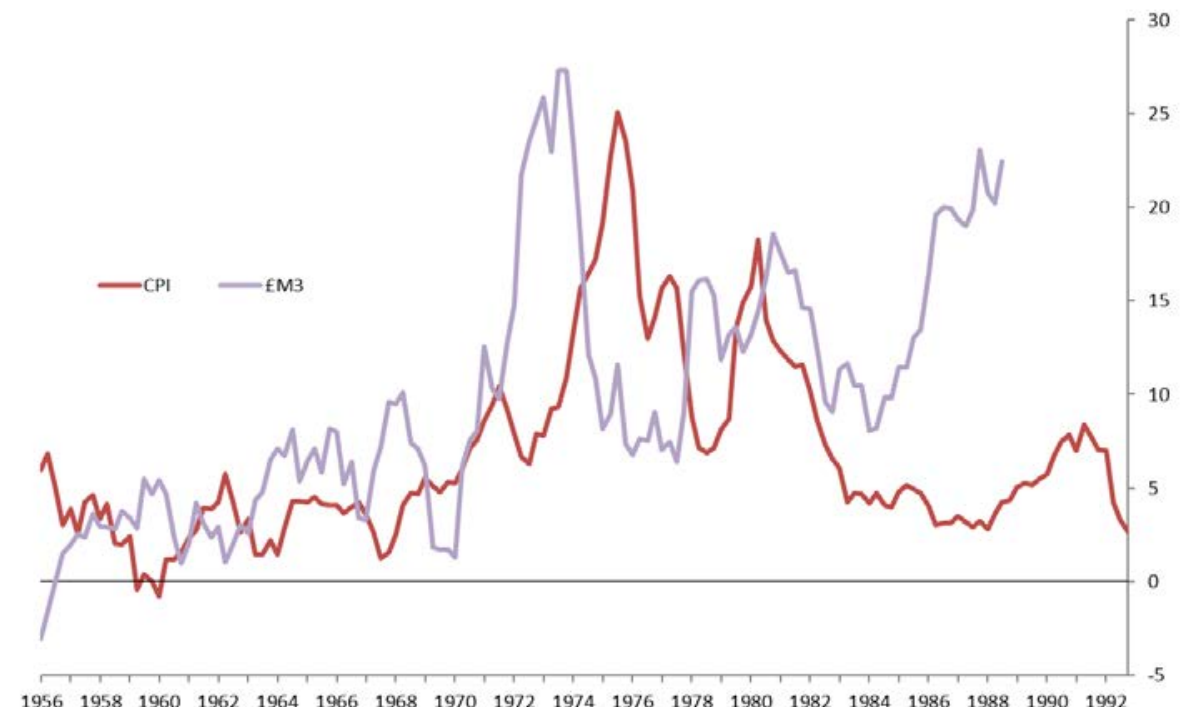

Source: Data from Michael Bordo, Oliver Bush and Ryland Thomas (2019) "UK Monetary and fiscal Policy Interactions in the Great Inflation" Bank of England

\section{Figure 14. UK Current Account and Public Sector Net Borrowing (\% of GDP)}

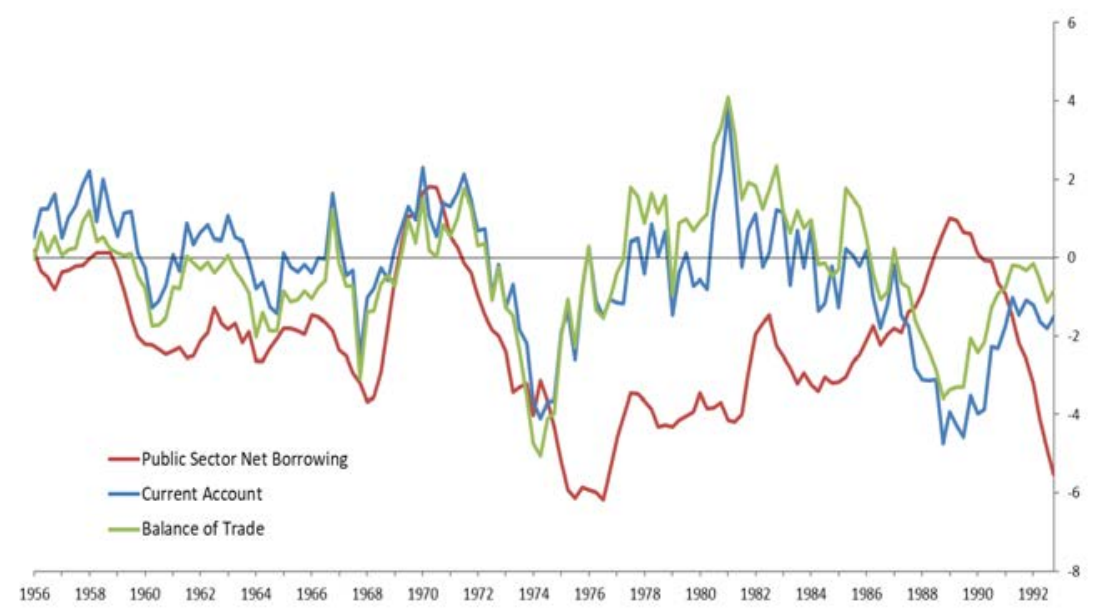

Source: Data from Michael Bordo, Oliver Bush and Ryland Thomas (2019) "UK Monetary and fiscal Policy Interactions in the Great Inflation" Bank of England 
Figure 15. US Government Debt (\% of GDP)

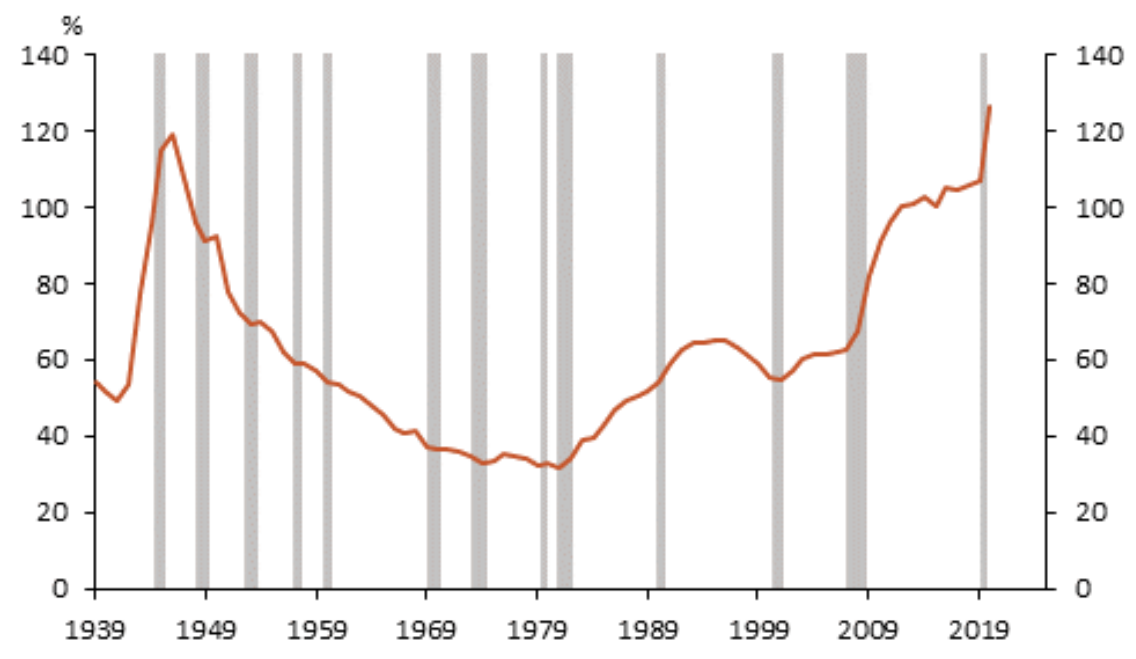

Source: Office of Management and Budget and Congressional Budget Office

Figure 16. US Monetary Base and Money Stock (M2) - (y-o-y \%)

$$
\begin{aligned}
& \text { Monetary Base } \\
& \text { \% Change - Year to Year SA, MII.\$ } \\
& \text { Money Stock: M2 } \\
& \text { \% Change - Yar to Year SA, Ell.\$ }
\end{aligned}
$$

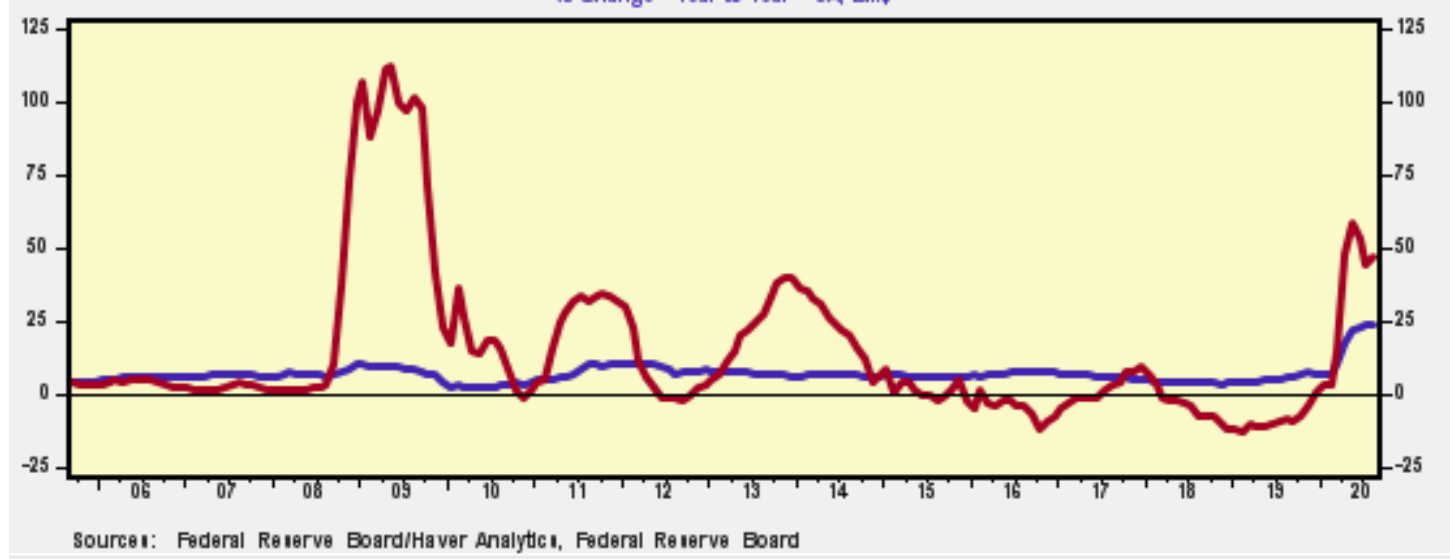

Source: Federal Reserve Board/Haver Analytics 
Figure 17. US - M2 over Monetary Base

M2/Monetary Base

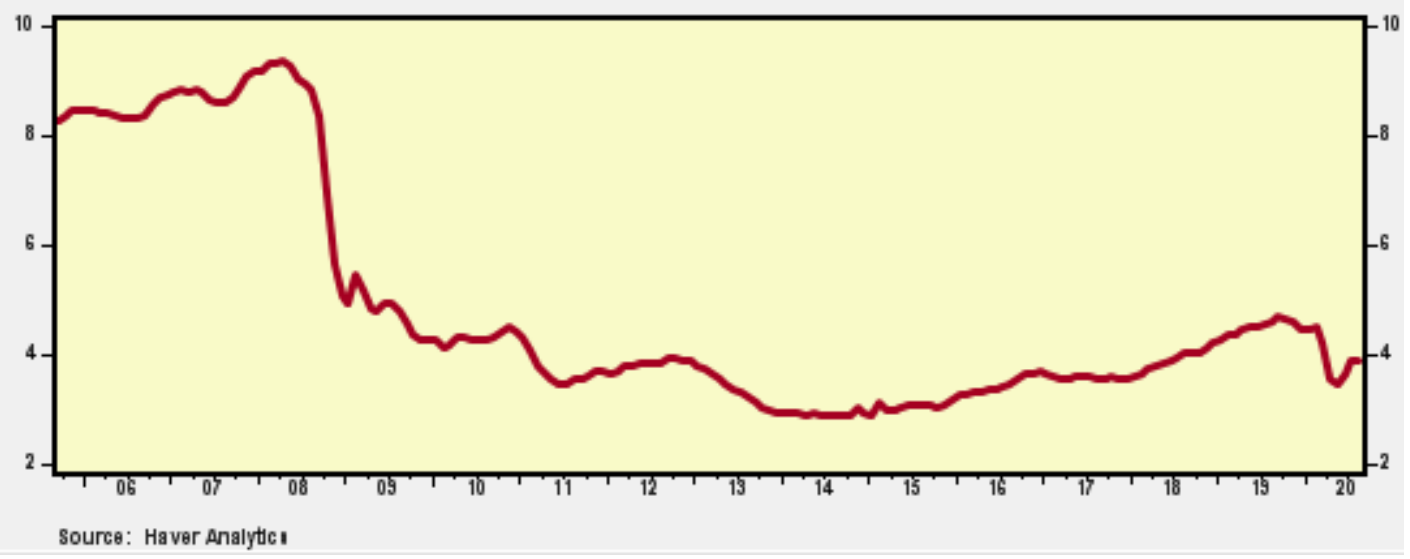

Source: Haver Analytics

Figure 18. US - Commercial Banks: Deposits and C\&I Loans (USD billion)

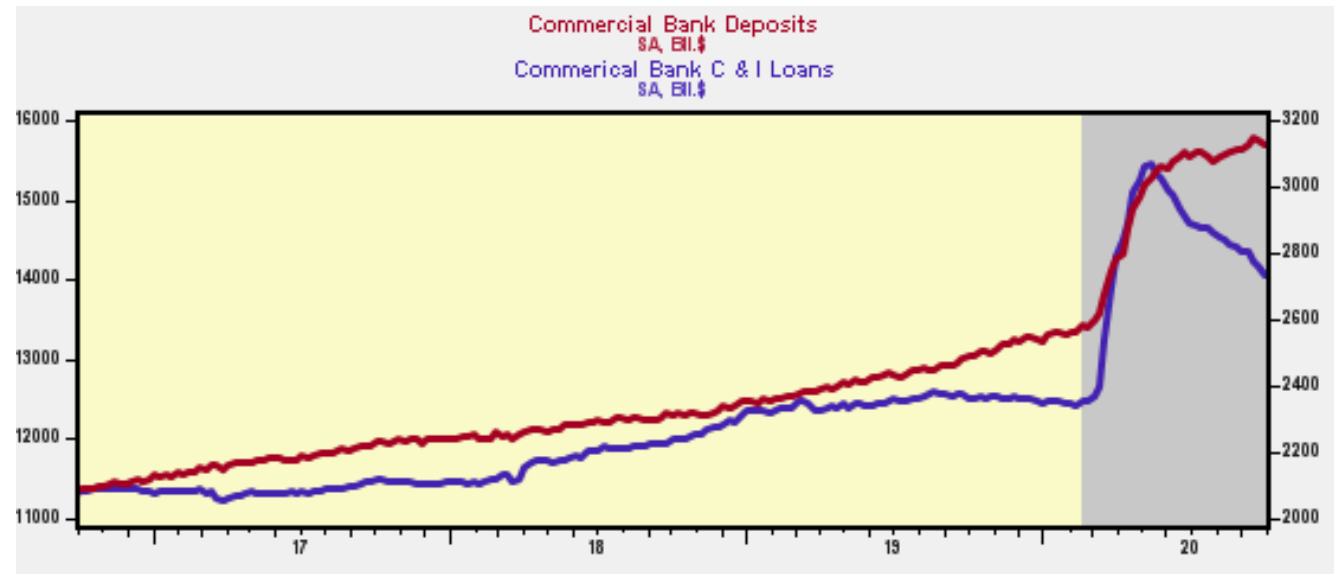

Source: Fideral Reırve Board/Haver Analytic

Source: Federal Reserve Board/Haver Analytics 
Figure 19. US - Personal Saving and Deposits: All Commercial Banks (USD billion)

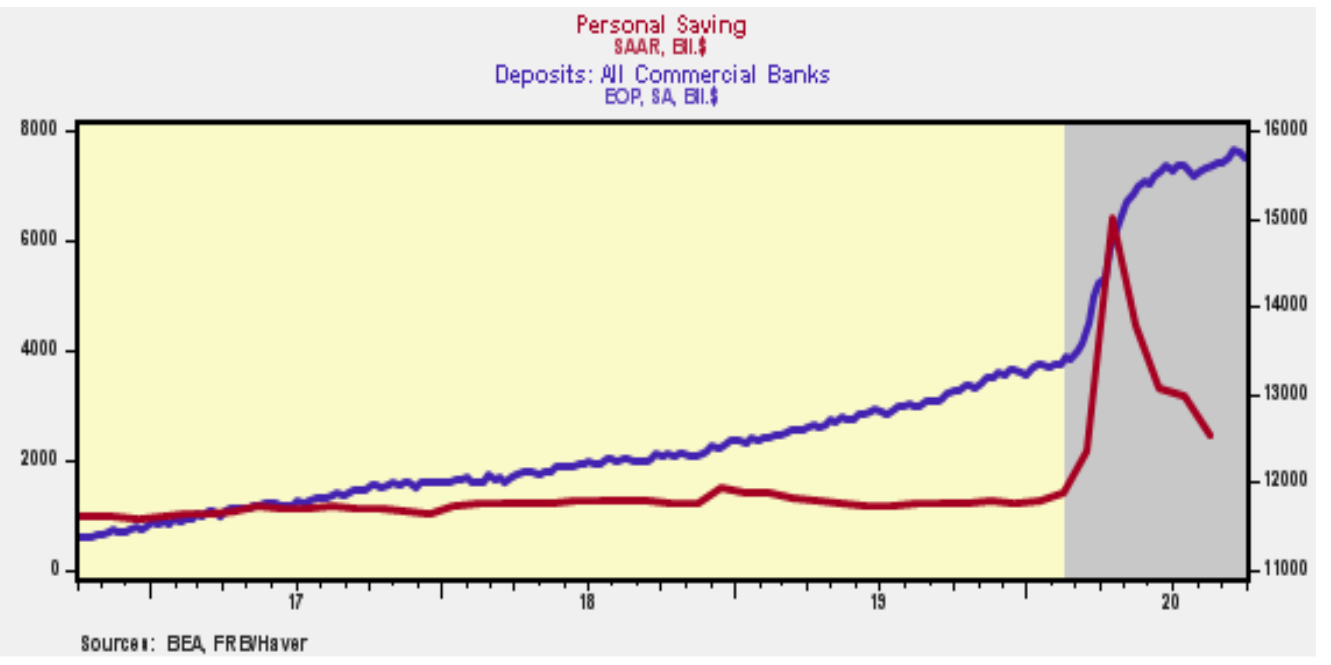

Source: BEA/Haver Analytics 


\section{References}

Shagil Ahmed (1986) "Temporary and Permanent Government Spending in an Open Economy: Some Evidence for the United Kingdom" Journal of Monetary Economics 1vol 17. no.2 197-221.

Joshua Aizenman and Nancy Marion (2010) “Using Inflation to Erode Public Debt" UC Santa Cruz (mimeo).

Leonall Anderson and Jerry L. Jordan (1968) “Monetary and Fiscal Actions: A Test of Their Relative Importance in Economic Stabilization". Federal Reserve Bank of St. Louis Review November.

Pamfila Antipa and Christophe Chamley (2017) “Monetary and Fiscal Policy in England During the French Wars (1793-1821) Boston University (mimeo).

Robert Barro (1987) “Government Spending, Interest Rates, Prices and Budget Deficits in the United Kingdom. Journal of Monetary Economics vol 20. No. 2 221-245.

Robert Barro (1979) "On the Determination of Public Debt" Journal of Political Economy. Vol 87 No.5 Part 1. October pp 940-971.

Ben Bernanke (2008) "Federal Reserve Policies in the Financial Crisis", Board of Governors of the Federal Reserve System, December.

Ben Bernanke (2012) "Monetary Policy Since the Onset of the Crisis", Federal Reserve Bank of Kansas City Jackson Hole Symposium, August 31.

Board of Governors of the Federal Reserve System (2020), "Minutes of the Federal Open Market Committee, November 4-5, 2020".

Michael Bordo and John Duca ( 2020a) “ How New Corporate Bond Programs Dampened the Financial Accelerator in the Covid-19 Recession" NBER Working Paper 28097 October. 
Michael Bordo and John Duca ( 2020b) " How the New Fed Municipal Bond Facility Capped Treasury Yield Spreads in the Covid -19 Recession" Rutgers University (mimeo) Novembver

Michael Bordo, Andrew Levin, and Mickey Levy (2020) "Incorporating Scenario Analysis into the Federal Reserve's Policy Strategy and Communications" NBER Working Paper June.

Michael Bordo, Oliver Bush and Ryland Thomas (2019) “UK Monetary and fiscal Policy Interactions in the Great Inflation" Bank of England (mimeo).

Michael Bordo (2018) “The Imbalances of the Bretton Woods System 1965 to 1973: U.S. Inflation, the Elephant in the Room" NBER WP 25409. December.

Michael Bordo, Christopher Erceg, Andrew Levin and Ryan Michaels (2017) “Policy Credibility and Alternative Approaches to Disinflation" Research in Economics vol 7 (3) pp 442-460.

Michael Bordo and Athanasios Orphanides (2013) The Great Inflation: The Rebirth of Modern Central Banking. Chicago: University of Chicago Press.

Michael Bordo, Ronald MacDonald and Michael Oliver (2009) "Sterling in Crisis 1964-1967" European Review of Economic History, October.

Michael Bordo and Pierre Cyrille Hautcoeur (2007) “Why Didn't France Follow the British Stabilization After World War I?" European Review of Economic History 11, 3-37.

Michael Bordo and Tamim Bayoumi (1998) “Getting Pegged: Comparing the 1879 and 1925 Gold Resumptions" Oxford Economic Papers. 
Michael Bordo (1993) “The Bretton Woods International Monetary System: A Historical Overview" chapter 1 in Michael Bordo and Barry Eichengeen (eds) A Retrospective on the Bretton Woods System: Lessons for International Monetary Reform. Chicago: University of Chicago Press.

Michael Bordo and Eugene White (1991) “: A Tale of Two Currencies: British and French Finance During the Napoleonic Wars" Journal of Economic History Vol 51 Issue 2 303-316.

Michael Bordo and Anna Schwartz (1981) "Money and Prices in the Nineteenth Century: Was Thomas Tooke Right?" Explorations in Economic History 18(2) pp97-127.

Michael Bordo and Anna Schwartz (1980) "Money and Prices in the Nineteenth Century: an Old Debate Revisited" Journal of Economic History. Vol XI No 1. (March). Michael Boskin (2020) “Are Large Deficits and Debt Dangerous?”, NBER Working Paper 26727, February.

John Brewer (1989) The Sinews of Power, War, Money and the English State 1650-1783. New York: A Knopf.

Arthur Burns (1979) "The Anguish of Central Banking" The Per Jacobsson Foundation, September.

Forrest Capie (1986) "Conditions in Which Very Rapid Inflation Has Appeared" Carnegie Rochester Series on Public Policy Vol 24 pp 115-168.

Richard Clarida (2020), "Fed Vice Chair Richard H.Clarida on U.S. Monetary Policy", The Peterson Institute for International Economics, August.

John Cochrane (2019) 'The Fiscal Theory of the Price Level' Hoover Institution (mimeo).

Congressional Budget Office (2011), Long-Term Budget Outlook, June.

Congressional Budget Office (2020), The 2020 Long-Term Budget Outlook, www.cbo.gov/publication/56516.

Riccardo DiCecio and Edward Nelson (2013) "The Great inflation in the United States and the United Kingdom: Reconciling Policy Decisions and Data Outcomes" chapter 8 in Michael Bordo 
and Athanasios Orphanides The Great Inflation: The Rebirth of Modern Central Banking. Chicago: University of Chicago Press

P.M. Dickson (1967) The Financial Revolution in England. London: MacMillan

JCR Dow (1964) The Management of the British Economy 1945-1960. London: Cambridge University Press.

Darrell Duffie (2020) "Still the World's Safe Haven: Redesigning the U.S. Treasury Market after the Covid-19 Crisis", The Brookings Institution.

Robert Eagly (1969) "Monetary Policy and Politics in Mid Eighteenth Century Sweden" Journal of Economic History December. Vol 20 No.4 739-757.

William Easterly, Paulo Mauro, Klaus Schmidt-Hebbel (1995) “Money Demand and Seigniorage Maximizing Inflation" journal of Money, Credit and banking vol 27 No.2 (May) 583-603.

Wendy Edelberg and Louise Sheiner (2020) "What could additional fiscal policy do for the economy in the next three years?", The Brookings Institution, October 9.

Gautti Eggertson (2008) "Great Expectations and the Ends of the Depression" American Economic Review 98(4) 1476-1511.

Torsten Ehlers (2011), "The Effectiveness of the Federal Reserve's Maturity Extension Program Operation Twist 2: the portfolio rebanancing channel and public debt management", BIS Papers No 65, September.

Barry Eichengreen (1992) Golden Fetters: The Gold Standard and The Great Depression. New York; Oxford University Press.

Martin Feldstein (1983) Inflation, Tax Rules, and Capital Formation, National Bureau of Economic Research, University of Chicago Press.

Martin Feldstein (2011) "The Economy Is Worse than You Think, Wall Street Journal, June 8.

Frank Fetter (1965) Development of British Monetary Orthodoxy 1793- 1815. Cambridge: Harvard University Press

Klas Fregert (2018) "Sveriges Riksbank: 350 Years in the Making" chapter 3 in Rodney Edvinson, Tor Jacobson and Daniel Waldenstrom (eds) Sverige Riksbank and the History of Central banking. New York: Cambridge University Press. 
Klas Fregert and Lars Jonung (1996) "Inflation and the Switches Between Specie and Paper Standards in Sweden 1668-1931: A Public Finance Interpretation" Scottish Journal of Political Economy 43: 419-443.

Milton Friedman (1969) The Optimum Quantity of Money Chicago: Aldine

Milton Friedman and Anna Schwartz (1963) A Monetary History of the United States 18671963. Princeton: Princeton University Press

Milton Friedman (1956) Studies in the Quantity Theory of Money. Chicago: University of Chicago Press.

Simon Gilchrist, Bin Wei, Vivian Yue and Egon Zakrajsek (2020) "The Fed Takes on Corporate Credit Risk: An Analysis of the Efficiency of the SMCCF", NBER Working Paper 27809, September.

Charles Goodhart (2020) “"Inflation after the pandemic: Theory and practice”, voxEU, June 13.

Charles Goodhart and Manoj Pradham (2020) The Great Demographic Reversal: Aging Societies, Waning Inequality, and the Inflation Revival, Palgrave Macmillan.

Alan Greenspan, Alfred Kahn, Marvin Kosters and Rudolph Oswald (1979) “On Carter's AntiInflation Policy, American Enterprise Institute, ISBN: 0-8447-2144-1, February.

Herschel Grossman (1990) "The Political Economy of War, Debt and Inflation" in Philip Cagan and William S. Haraf (eds) Monetary Policy in a Changing Environment. Washington DC. American Enterprise Institute.

George Hall and Thomas Sargent (2020) “Debt and Taxes in Eight U.S. Wars and Two Insurrections" Handbook of Historical Economics

Owen Humpage (2015) "Even Keel and the Great Inflation" Federal Reserve Bank of Cleveland Working paper 15/32 December.

Owen Humpage (2016) “Fiscal Dominance and U.S. Monetary Policy: !940-1975” Federal Reserve Bank of Cleveland Working Paper 16/32 December.

Peter Ireland (2020) "End Interest on Bank Reserves", Shadow Open Market Committee, October.

Peter Ireland and Mickey D. Levy (2017) “A Strategy for Normalizing Monetary Policy, Shadow Open Market Committee.

Margaret Jacobson, Eric Leeper and Bruce Preston (2019) “Recovery of 1933” NBER WP 25629 
March.

A.J Jalil and G Rua (2017) "Inflation Expectations in the U.S. in Fall 1933" Research in Economic History (eds) S. Wolcott and C Hanes vol 33 pp 139-169.

Harold James ( 2020) Making a Modern Central Bank: The Bank of England 1979-2003.

Cambridge UK:Cambridge University Presss

Jerry Jordan (2016) "The New Monetary Framework", Cato Journal, Vol 36 (Spring/Summer), pp. 367-383.

Kathryn Judge (2020) "Why the Fed Should Issue a Policy Framework for Credit Policy", prepared for the Shadow Open Market Committee, September 30.

Nicholas Kaldor (1966) Causes of the Slow Rate of Growth of the United Kingdom. London. Cambridge University Press.

Eric Leeper (1991) “Equilibria under 'Active' and “Passive' Monetary and Fiscal Policy “Journal of Monetary Economics 27(1) pp 129-147.

Eric Leeper and Todd Walker (2011) "Perceptions and Misperceptions of Fiscal Inflation" BIS Working Paper no.364 November.

Eugene Lerner (1956) “Inflation in the Confederacy 1861-1865' in Milton Friedman, Studies in the Quantity Theory of Money. Chicago: University of Chicago Press

Mickey D. Levy (2017) “Monetary Policy for Healthy Economic Performance” U.S. Congress House Financial Services Committee, November Testimony.

Mickey D. Levy (2017) “Why Have the Fed's Policies Failed to Stimulate the Economy? Cato Journal, 37 (1), 39-45.

Mickey D. Levy (2020) “Money Supply Spike: Sources and Implications”, Berenberg Capital Markets, July 1.

Mickey D. Levy (2020) “The Fed's Aggressive Response to the Crisis: What's Next?" Berenberg Capital Markets, July 23.

Robert Lipsey (1960) "The Relationship Between Unemployment and the Rate of Change of Money Wages in the U.K. 1862-1957: A Further Analysis" Economica New Series Vol 27 No. 100 (Feb), pp 1-31.

Allan Meltzer (2010) A History of the Federal Reserve Volume 2. Chicago: University of Chicago Press 
Allan Meltzer (2005) A History of the Federal Reserve Volume 1 1913-1951. Chicago: University of Chicago Press

Bill Nelson (2020) "Bill Nelson and the Fed's Policy Tools in the Post-COVID Economy", George Mason University Mercatus Center, Podcast July 2020.

Patrick O’Brien (1967) “Government Revenues 1793-1815 A Study of Fiscal and Financial Policy in the War Against France" Ph.D. Dissertation. University of Oxford

Lee Ohanaian (1997) "The Macroeconomic Effect of War Finance in the United States: World War II and the Korean War" American Economic Review.

Jerome Powell (2019), "Opening Remarks" at Conference on Monetary Policy Strategy, Tools and Communications Practices, sponsored by the Federal Reserve Bank of Chicago, June.

Jay Powell (2020) "New Economic Challenges and the Fed's Monetary Policy Review", Federal Reserve Bank of Kansas City Jackson Hole Symposium, August 27.

Jay Powell (2020) "Recent Economic Developments and Challenges Ahead", NABE Virtual Annual Meeting, October 6.

Carmen Reinhart and M.B. Sbrancia (2015) "The Liquidation of Government Debt" Economic Policy Vol 30, Issue 82 April

Richard Roberts (2017) When Britain Went Bust-The 1976 IMF Crisis. London: OMFIF Press.

Hugh Rockoff (2016) "War and Inflation in the United Sates from the Revolution to the Persian Gulf War" in Jari Eloranta et al (eds) Economic History of Warfare and State Formation. Studies in Economic History. Pp 159-195.

Christina Romer (1992) “What Ended the Great Depression?” Journal of Economic History 52(4) 753-784.

Thomas Sargent and Neil Wallace (1981) “Some Unpleasant Monetarist Arithmetic" Federal Reserve Bank of Minneapolis Quarterly Review, Fall.

E. Schumpeter (1938) English Prices and Public Finance 160-1820" Review of Economics and Statistics XX 21-32.

Anna J Schwartz (1973) "Secular Price Change in Historical Perspective" Journal of Money, Credit and banking. Vol 5 no.1 February pp 243-269. 
George P Shultz (2018) “Dreams Can Be Nightmares" Online Appendix. Journal of Economic History June.

N. Silberling (1923) "British Prices and Business Cycles" Review of Economics and Statistics. October.

Christopher Sims (2020) "How to Worry About Government Debt" Markus Academy webinar. Princeton University Bendheim Center for Finance. October 15

Christopher Sims (2011) "Stepping on a Rake; the Role of Fiscal Policy in the Inflation of the 1970s' European Economic Review Vol 55(1) pp 48-56 January.

Kevin Hassett, Casey Mulligan, Timothy Fitzgerald and Cody Kallen (2020) "An Analysis of Vice President Biden's Economic Agenda: The Long-Run Impacts of Its Regulations, Taxes and Spending", The Hoover Institution, October 15

Herbert Stein (1990), The Fiscal Revolution in America, The American Enterprise Institute.

Herbert Stein (1994) Presidential Economics. Third Edition Washington DC: American Enterprise Institute

Henry Thornton (1802) An Inquiry into the Nature and Effects of the Paper Credit of Great Britain. London.

Wyatt C. Wells (1994) Economics in an Uncertain World Arthur F. Burns and the Federal Reserve 1970-78. New York: Columbia University Press.

Eugene White (1995) "The French Revolution and the Politics of Government Finance 17701815" Journal of Economic History June. Vol 51, No 2 227-255.

John Taylor (2007) "Housing and Monetary Policy", Federal Reserve Bank of Kansas City Jackson Hole Economic Symposium.

Jacob Viner (1937) Studies in the Theory of International Trade. Chicago: University of Chicago Press.

Paul Volcker (1979) "Confirmation Hearings Before the Senate Committee on Banking, Housing and Urban Affairs", July 30. 